University of California, Hastings College of the Law UC Hastings Scholarship Repository

Faculty Scholarship

2015

\title{
The Future of Polyamorous Marriage Lessons from the Marriage Equality Struggle
}

Hadar Aviram

UC Hastings College of the Law, aviramh@uchastings.edu

Gwendolyn Leachman

Follow this and additional works at: http://repository.uchastings.edu/faculty_scholarship

\section{Recommended Citation}

Hadar Aviram and Gwendolyn Leachman, The Future of Polyamorous Marriage Lessons from the Marriage Equality Struggle, 38 Harvard Journal of Law \& Gender 269 (2015).

Available at: http://repository.uchastings.edu/faculty_scholarship/993

This Article is brought to you for free and open access by UC Hastings Scholarship Repository. It has been accepted for inclusion in Faculty Scholarship by an authorized administrator of UC Hastings Scholarship Repository. For more information, please contact marcusc@uchastings.edu. 


\section{THE FUTURE OF POLYAMOROUS MARRIAGE: LESSONS FROM THE MARRIAGE EQUALITY STRUGGLE}

\section{Hadar Aviram* \& Gwendolyn M. Leachman***t}

Amidst the recent legal victories and growing public support for samesex marriage, numerous polyamorous individuals have expressed interest in pursuing legal recognition for marriages between more than two consenting adults. This Article explores the possibilities that exist for such a polyamorous marriage equality campaign, in light of the theoretical literature on law and social movements, as well as our own original and secondary research on polyamorous and LGBT communities. Among other issues, we examine the prospect of prioritizing the marriage struggle over other forms of nonmarital relationship recognition; pragmatic regulative challenges, like taxation, healthcare, and immigration; and how law and culture shape these struggles and their ability to produce social change.

We argue that legal mobilization for same-sex marriage has produced conflicting pressures for contemporary polyamorous activism. On one hand, same-sex marriage litigation has provided several doctrinal footholds for expanding marriage to polyamorous relationships. On the other hand, samesex marriage litigation has simultaneously reinforced cultural stigmas against polyamorous relationships_-stigmas that constrain the practical utility of those legal tools (especially as means for implementing broader social change beyond the letter of the law). By accounting for these conflicting legal and cultural pressures, this Article provides a comprehensive roadmap of the issues, strategies, and challenges likely to emerge along the path toward polyamorous marriages.

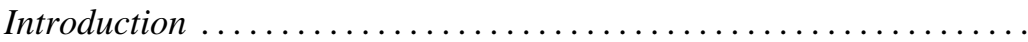

I. Historical Background on Same-Sex Marriage Activism .... 279

A. Gay Liberation and Marriage Litigation as Protest .... 280

B. Gay Rights Advocacy Puts Marriage on the Fringe .... 286

* Professor of Law, Harry and Lillian Hastings Research Chair, UC Hastings College of the Law.

** Assistant Professor of Law, University of Wisconsin-Madison.

$\dagger$ We are very grateful to Michael Boucai and Ed Stein, as well as to the Frontiers in Sexuality Colloquium and the Conference on the Future of Monogamy and Nonmonogamy participants for their helpful comments, and to Deanna Dyer for her valuable research assistance.

$\$$ The interview transcripts and field notes referenced in this Article were collected by this Article's first author in previous studies. The disclosure of these documents would violate institutional review board and ethical standards. Accordingly, these materials have not been checked for substantive accuracy by the Harvard Journal of Law \& Gender's editorial team. The Journal cannot independently attest to the content of these materials. 
C. Marriage Equality Enters the Mainstream ........... 290

II. The Polyamorous Community and Its (Multiple) Views on Marriage .................................... 297

III. Legal and Extralegal Lessons From the Marriage Equality Struggle .................................. 308

A. Legal Arguments ............................ 309

B. Extralegal Strategies and Challenges ............ 322

C. Alternatives to Marriage ..................... 328

IV. Discussion and Implications .................... 331

Conclusion ........................................ 335

The radical of one century is the conservative of the next. The radical invents the views. When he has worn them out, the conservative adopts them. ${ }^{1}$

\section{INTRODUCTION}

On June 26, 2013, hundreds of San Franciscans swarmed excitedly into City Hall in the early morning hours. ${ }^{2}$ Giant video screens were positioned for the audience's benefit to capture the Supreme Court decision announcements of that morning in two important cases: United States v. Windsor, ${ }^{3}$ addressing the constitutionality of the federal Defense of Marriage Act (DOMA), and Hollingsworth v. Perry, ${ }^{4}$ addressing the viability of California's Proposition 8. City Hall had been Ground Zero for the latter legal challenge; in 2004, then-Mayor Gavin Newsom opened its doors to same-sex couples seeking to get married, in violation of a then-existing California statute forbidding same-sex marriages. ${ }^{5}$ The San Francisco Superior Court found the statute to be unconstitutional. ${ }^{6}$ Shortly thereafter, in 2008 , voters passed Proposition 8, a California constitutional amendment forbidding same-sex marriage. ${ }^{7}$ In 2010, Judge Vaughn Walker found Prop 8 unconstitutional. $^{8}$

\footnotetext{
${ }^{1}$ Mark Twain at Your Fingertips: A Book of Quotations 393 (Caroline Thomas Harnsberger ed., Dover Publ'ns 2012) (1948).

${ }^{2}$ Matthew S. Bajko \& Lisa Keen, Court Victories!, Bay Area Rep., June 27, 2013, archived at http://perma.cc/PT96-795Q. The first author attended this occasion at City Hall.

3133 S. Ct. 2675 (2013).

${ }^{4} 133$ S. Ct. 2652 (2013).

${ }^{5}$ San Francisco Weds Gay Couples, CNN (Feb. 12, 2004), archived at http:// web.archive.org/web/20040609103629/http://www.cnn.com/2004/LAW/02/12/ gay.marriage.california.ap/.

${ }^{6}$ In re Coordination Proceeding, Special Title Rule 1550(c), No. 4365, 2005 WL 583129 , at $* 12$ (Cal. Super. Ct. Mar. 14, 2005).

${ }^{7}$ For a discussion of the passage of Proposition 8 and the lawsuits surrounding it, see generally Scott Cummings \& Douglas NeJaime, Lawyering for Marriage Equality, 57 UCLA L. REV. 1235 (2010).

${ }^{8}$ See Perry v. Schwarzenegger, 704 F. Supp. 2d 921, 997 (N.D. Cal. 2010).
} 
The State of California did not appeal the ruling, ${ }^{9}$ and when the initiative's proponents continued the struggle to prevent same-sex marriages, ${ }^{10}$ the $\mathrm{Su}$ preme Court ruled they had no standing to do so. ${ }^{11}$

As the decisions in both cases were announced on CNN, spectators excitedly exclaimed and squealed. ${ }^{12}$ The combined effects of the decisionsthe first declaring Section 3 of DOMA unconstitutional, ${ }^{13}$ the second putting an end to the barriers to same-sex marriage in California on procedural grounds ${ }^{14}$ - would be that thousands of San Franciscan couples could marry, and that same-sex marriages in states that allowed them would be fully recognized by the federal government, including for purposes of taxation, health care, and immigration. ${ }^{15}$ Former Mayor Newsom, Mayor Ed Lee, City Attorney Dennis Herrera, and Phyllis Lyon, the original petitioner in the marriage cases and the first person to be married at City Hall to her female partner, came down the stairs, welcomed by deafening applause and cheers. ${ }^{16}$ As the joyous news sank in, celebrations outside City Hall began, later to continue in the Castro, San Francisco's historical gay neighborhood. ${ }^{17}$

This account of Windsor and Perry exemplifies several of the extralegal outcomes of legal mobilization, which previous socio-legal scholarship has examined in detail. ${ }^{18}$ The public celebrations around the recent Supreme Court decisions-echoing the alternating rounds of celebration and protest in response to marriage decisions in previous years-illustrate how marriage equality litigation has sparked renewed interest and popular participation in LGBT politics. Same-sex marriage and relationship recognition litigation have also helped to reconstruct the dominant cultural meanings associated with marriage, bringing same-sex couples within its ambit. ${ }^{19}$ Since the

${ }^{9}$ Press Release, State of Cal. Dep't of Justice Office of the Att'y Gen., Attorney General Kamala D. Harris Issues Statement on Prop. 8 Arguments (Mar. 26, 2013), archived at http://perma.cc/BH52-RYPS.

${ }^{10}$ Bob Egelko, High Court Won't Order State to Defend Prop 8, S.F. Chron., Sept. 9, 2010, archived at http://perma.cc/5JBD-UUZF.

${ }^{11}$ Hollingsworth v. Perry, 133 S. Ct. 2652, 2652-53 (2013).

${ }^{12}$ Bajko \& Keen, supra note 2.

${ }^{13}$ United States v. Windsor, 133 S. Ct. 2675, 2682 (2013).

${ }^{14}$ Hollingsworth, 133 S. Ct. at 2659.

${ }^{15}$ See generally After DOMA, LAMBDA LeGAL, archived at http://perma.cc/C8JY$83 \mathrm{H} 2$ (summarizing the consequences of Windsor); Frequently Asked Questions: Defense of Marriage Act (DOMA), GLAAD, archived at http://perma.cc/9K3U-SB3Z (same).

${ }^{16}$ Bajko \& Keen, supra note 2.

${ }_{17}$ Jim Wilson, Joy, and Dismay, as the Supreme Court Rules, N.Y. Times, June 26, 2013, archived at http://perma.cc/KM4E-N2UM (depicting a celebration in the Castro neighborhood in photo 8).

${ }^{18}$ See, e.g., Michael McCann, Rights at Work: Pay Equity Reform and the Politics of Legal Mobilization 5-6 (1994) (including broad changes in public policies and social practices in the analysis of legal mobilization); Marc Galanter, The Radiating Effects of Courts, in EMPIRICAL Theories About Courts 117 (Keith O. Boyum \& Lynn Mather eds., 1983) (examining the flow of influence outward from courts).

${ }^{19} C f$. Kathleen E. Hull, Same-Sex Marriage: The Cultural Politics of Love AND LAw 76 (2006) ("As . . excluded [same-sex couples] appropriate those elements of the institution that are least easily restricted (in the case of marriage, its cultural practices), the institution itself begins to transform."). 
LGBT civil rights organizations came to prioritize marriage litigation, public acceptance for same-sex marriage has risen dramatically, from $27 \%$ in March 1996 to 53\% in May 2013..$^{20}$ The litigation campaign for same-sex marriage has also resulted in a rising tide of legal victories on the issue, ${ }^{21}$ creating formal rights that many same-sex couples around the nation benefit from directly. Even acknowledging the strong criticisms marriage litigation has evoked, both among antigay conservatives and within the LGBT community itself, ${ }^{22}$ most people would probably agree that the legal mobilization around marriage has invigorated the LGBT movement and has improved the situation of many sexual minorities in a predominantly heterosexual society.

Missing from this standard celebratory account of marriage equality litigation is an assessment of an entirely different class of extralegal effectsspecifically, the effects that marriage equality litigation may have produced for sexual minority communities outside the context of the LGBT movement. Indeed, this is an oversight of the legal mobilization literature more broadly. While significant work has been done to examine the extralegal impact of legal mobilization on the specific constituencies whose legal rights are formally implicated, there has been little empirical research into the impact of legal mobilization on other, related social groups, or the conditions under which such an impact is most likely to occur. This oversight is particularly surprising given that the legal constructs evoked through legal mobilization (e.g., marriage, rights, equality) tend to resonate with a broad array of non-movement actors $^{23}$ - suggesting that a movement's politiciza-

${ }^{20}$ Marriage, Gallup, http://www.gallup.com/poll/117328/marriage.aspx, archived at http://perma.cc/BAG6-L3RB. By July 2013, after the Windsor and Perry decisions, the percentage of supporters rose to $54 \%$. Id.

${ }^{21}$ Since the Supreme Court's Windsor and Perry decisions in June 2013, there have been sixty-five rulings against state bans on same-sex marriage. Marriage Rulings in the Courts, Freedom to MARRY, archived at http://perma.cc/C2S8-G4TJ (documenting same-sex marriage cases since June 2013, current as of March 2, 2015).

${ }^{22}$ Among the critiques of marriage within the LGBTQ community are its tendency to pressure LGB assimilation into state-favored dyadic, monogamous couplings, see Blair McVicar, Forget Same-Sex Marriage, Heteronormativity is the Real Problem, Literati Co. (Nov. 21, 2013), http://literatico.com/features-and-opinion/the-gender-card/forgetsex-marriage-heteronormativity-real-problem, archived at http://perma.cc/8X4R-86XV, and that winning marriage benefits is most relevant to the LGBT community's white and wealthy segments (rather than the poor and of color segments of the community), which are most likely to form marital relationships, see Marcus Anthony Hunter, Race and the Same-Sex Marriage Divide, 12 ConTEXTs 74, 74-75 (2013).

${ }^{23}$ See Hull, supra note 19, at 76 ("The cultural practices that partially constitute marriage have a strong pull on many people, including some who are excluded from marriage as a legal institution. This is true not only of contemporary same-sex couples, but of other excluded relationships as well. American slaves were forbidden legal marriage but constructed wedding rituals for themselves outside the law. And polygamists, both historically and in the present, draw on the cultural trappings of marriage to enact their 'plural marriages,' despite the absence of legal recognition and even the threat of criminal prosecution.”). 
tion of these terms is likely to generate "spillover" effects in other social groups. ${ }^{24}$

This Article addresses the idea of legal mobilization "spillover" by examining the implications of the LGBT movement's marriage equality campaign for a sympathetic, but distinct, sexual minority group: the polyamorous community. Polyamorous (or "poly") relationships are sexually intimate relationships between three or more consenting adults. The polyamorous community distinguishes itself from the religious variant of multiparty relationships, polygamy, in its members' ethical commitment to nonmonogamy ${ }^{25}$ and acceptance of queer sexualities. Many in the poly community also view the LGBT community as a natural affinity group-so much so that politicized poly activists have historically restrained themselves politically to avoid stepping on the toes of LGBT activists. ${ }^{26}$ In 2005, this Article's first author conducted an ethnography of Bay Area polyamorous activists and found reluctance to pursue legal avenues, among other reasons, out of fear of sabotaging the marriage equality struggle. ${ }^{27}$ Yet the increasingly victorious legal mobilization around same-sex marriage appears to have emboldened activists to speak out on the issue. For example, Tobi Hill-Meyer of Seattle expressed her complex feelings in reaction to Windsor and Perry in her blog post, titled "I Still Can't Marry My Partner": ${ }^{28}$

However, in your celebrations I want to ask one teeny little favor of you. Please don't say "all couples have the freedom to marry" or "We finally have marriage equality." . . . [E]ven in states with same sex-marriage [sic], the statement that "everyone can get married now" is just not true. I live in Seattle, and have been hearing this a lot since our state passed same-sex marriage last November. . . . But you see, here's the thing: I still can't marry

${ }^{24}$ See David S. Meyer \& Nancy Whittier, Social Movement Spillover, 41 Soc. Problems 277, 277 (1994) (analyzing mechanisms of transmission of ideas, tactics, style, participants, and organizations between movements).

${ }^{25}$ See Elizabeth Emens, Monogamy's Law: Compulsory Monogamy and Polyamorous Existence, 29 N.Y.U. Rev. L. \& Soc. Change 277, 283 (2004) ("Polyamory is a lifestyle embraced by a minority of individuals who exhibit a wide variety of relationship models and who articulate an ethical vision that I understand to encompass five main principles: self-knowledge, radical honesty, consent, self-possession, and privileging love and sex over other emotions and activities such as jealousy."). Note, however, that practices constituting polyamory can be quite distinct. See Christian Klesse, Polyamory: Intimate Practice, Identity or Sexual Orientation?, 17 Sexualities 81, 89 (2014) (“As a relational practice, polyamory sustains a vast variety of open relationship or multi-partner constellations, which can differ in definition and grades of intensity, closeness and commitment.").

${ }^{26}$ Hadar Aviram, Make Love, Not Law: Perceptions of the Marriage Equality Struggle Among Polyamorous Activists, 7 J. Bisexuality 261, 273-74 (2008) [hereinafter Aviram, Make Love, Not Law].

${ }^{27} I d$. at 273.

${ }^{28}$ Tobi Hill-Meyer, I Still Can't Marry My Partner, Bilerico Project (June 28, 2013), http://www.bilerico.com/2013/06/i_still_cant_marry_my_partner.php, archived at http://perma.cc/V2RU-HAKD. 
my partner of 8 years, Ronan Kelly. Because it would mean I couldn't be married to my partner of 15, Fay Onyx.

I know, I know, the marriage movement doesn't want to talk about poly families at all. I've accepted that none of you are going to fight for my marriage to be considered equal. It's been bashed over my head forever that I'm not even supposed to talk about my relationships because we are the evil end of the slippery slope along with bestiality and pedophilia. I'm not asking for you to fight for my rights. I'm just asking you not to pretend that everyone has the right to marry when my family can't even get a civil union..$^{29}$

Hill-Meyer is not alone; there seems to be a growing interest within the polyamorous community in legal recognition for multiparty relationships. In a 2012 survey conducted by the polyamorous magazine Loving More and the National Coalition for Sexual Freedom (NCSF), yielding 4062 responses from respondents ranging in age from 16 to $92,65.9 \%$ of respondents said they would take advantage of plural marriage if it were legally available. ${ }^{30}$ While the Loving More survey did find considerable ambivalence regarding governmental interference in relationships ${ }^{31}$ a sentiment also reflected in the first author's 2005 ethnographic work, ${ }^{32}$ the survey suggests that the poly community's ambivalence toward marriage is now coupled with newfound enthusiasm for legal mobilization, possibly in light of the successes of the LGBT community.

${ }^{29} I d$. Recounting the health care and immigration challenges of her multipartner family, and those of friends, Hill-Meyer adds:

I look at giddy proposals and declarations of love on Facebook and I have to admit, it stings to see so many friends being recognized in a way that I can't. It makes me want that too. Maybe not as much as I want an end of police profiling and harassment of queer youth, people of color, and trans women, but I definitely want it.

When I hear "Everyone can marry their partner now" and I have to add "except me" silently in my head, a little part of me is crushed. I swallow my tears and mumble something about marriage being just a piece of paper and try to get on with my day.

I'm not asking you to stop celebrating, or even to fight for my rights the same way I've fought for yours. But maybe you could avoid erasing me with your words. Maybe you could remember that we're not all equal yet. Certainly not in terms of employment, voting rights, or the criminalization of poverty. And not even in terms of marriage.

Id.

${ }^{30}$ What Do Polys Want?: An Overview of the 2012 Loving More Survey, Loving More (June 21, 2012), http://www.lovemore.com/polyamory-articles/2012-lovingmorepolyamory-survey/, archived at http://perma.cc/9XSZ-KEGL.

${ }^{31}$ The Loving More survey reported that $66.9 \%$ of respondents thought that no relationship structure "deserve[d] special recognition," indicating ambivalence about the privilege of marriage in general. $I d$. Part I discusses a similar ambivalence in the pre1993 LGBT movement and argues that it was not incompatible with activists' concerted political efforts demanding marriage equality at that time.

${ }^{32}$ Aviram, Make Love, Not Law, supra note 26, at 274-75, 277-80. 
While same-sex marriage litigation may have opened the door to an emulative multiparty marriage campaign, it has simultaneously undercut the potential for this campaign to be effective (at least in the short term). Samesex marriage advocates have strategically drawn a clear boundary between the struggle for same-sex marriage and a possible struggle for multiparty marriage. This rhetorical move is typically made to address the "slippery slope" arguments by conservatives that expanding marriage to same-sex couples would lead to further expansions for bigamy, polygamy, and incest. ${ }^{33}$ The following vignette provides a recent example of the slippery slope argument, as presented by Justice Sonia Sotomayor in the oral arguments of Hollingsworth v. Perry, followed by the defensive response by attorney Ted Olson, who represented the same-sex couples:

Justice Sotomayor: If you say that marriage is a fundamental right, what State restrictions could ever exist? Meaning, what State restrictions [would remain] with respect to the number of people ... that could get married [or] the incest laws[?] . . I can accept that the State has probably an overbearing interest on-on protecting a child until they're of age to marry, but what's left?

Mr. Olson: Well, you've said-you've said in the cases decided by this Court that the polygamy issue, multiple marriages raises questions about exploitation, abuse, patriarchy, issues with respect to taxes, inheritance, child custody, it is an entirely different thing. And if you-if a State prohibits polygamy, it's prohibiting conduct. If it prohibits gay and lesbian citizens from getting married, it is prohibiting their exercise of a right based upon their status. ${ }^{34}$

Instead of defending multiparty marriage, Olson reaffirms the general tendency among same-sex marriage supporters to insist that same-sex marriage would not lead to multiparty marriage-implicitly accepting the devaluation of multiparty relationships that the slippery slope arguments entail. Olson's response also subscribes to common stereotypes that multiparty marriages

${ }^{33}$ For example, social conservative Rick Santorum stated in 2003 that:

If the Supreme Court says that you have the right to consensual (gay) sex within your home, then you have the right to bigamy, you have the right to polygamy, you have the right to incest, you have the right to adultery. You have the right to anything ... [ [w] hether it's polygamy, whether it's adultery, whether it's sodomy, all of those things, are antithetical to a healthy, stable, traditional family.

Excerpt from Santorum Interview, USA TODAY (Apr. 22, 2003), archived at http://perma .cc/6Z8V-5KZV. Santorum reiterated this view at a public appearance in New Hampshire. Sandhya Somashekhar, Rick Santorum Compares Same-Sex Marriage to Polygamy, in Spirited Exchange at N.H. College, WASH. Post, Jan. 5, 2012, archived at http://perma .cc/BNH7-33FJ.

${ }^{34}$ Transcript of Oral Argument at 46-47, Hollingsworth v. Perry, 133 S. Ct. 2652 (2013) (No. 12-144), http://www.supremecourt.gov/oral_arguments/argument_trans cripts/12-144a.pdf, archived at http://perma.cc/5YEK-UXTE. 
generate "exploitation, abuse, patriarchy," but presents no data to support this assumption. ${ }^{35}$

Aside from creating thorny legal precedent for future multiparty marriage activists to confront, arguments like Olson's also create more immediate social repercussions for polyamorous communities. To begin with, these arguments have embittered many polyamory activists who once supported the same-sex marriage struggle. These instances dovetail with surveys of LGBT people finding a majority of participants objecting to legal recognition for relationships between more than two adults. ${ }^{36}$ The LGBT movement's simultaneous politicization of marriage and erection of a clear rhetorical wedge between same-sex and multiparty relationships may have even reinforced the stigmatization of multiparty relationships and nonmonogamous families.

This Article explores the future of marriages between more than two consenting adults, in light of the theoretical literature on law and social movements, as well as our own original and secondary research on polyamorous and LGBT communities. A motivating question in this research is how legal mobilization for same-sex marriage has constrained the set of legal and extralegal strategies available to advocates of multiparty marriagewhile potentially enabling other directions for advocacy. Previous legal and sociological literature has shown how particular social movement strategies (typically those that are viewed as most successful) tend to become engrained into a standard "toolkit" of political tactics that are borrowed from movement to movement. ${ }^{37}$ Our project builds on this idea of diffusion or "spillover" among movement strategies. However, instead of showing how effective strategies travel, our work considers how movement actors' very perceptions of a strategy's effectiveness may be shaped by a prior movement's legal mobilization. Specifically, we examine how a prior movement's

${ }^{35}$ Olson's response also draws a distinction between "conduct" and "the exercise of a right based upon status" that is murky at best. After all, marriage - between partners of any number or gender-is a type of "conduct." Furthermore, whether or not prohibitions on multiparty marriages are based on status depends upon whether polyamory (or one's polyamorous orientation) is a status - and at least some commentators have argued that it could be perceived as such. See generally Ann E. Tweedy, Polyamory as a Sexual Orientation, 79 U. CIN. L. REv. 1461 (2011) (arguing that the definition of sexual orientation should be expanded to include polyamory).

${ }^{36}$ See The Advocate Poll, Advocate, July 4, 2006, at 10.

${ }^{37}$ See, e.g., Doug McAdam \& Dieter Rucht, The Cross-National Diffusion of Movement Ideas, 528 Annals Am. Acad. Pol. \& Soc. Sci. 56, 58 (1993) (examining the spread of movement tactics and ideas across national lines); David S. Meyer \& Steven A. Boutcher, Signals and Spillover: Brown v. Board of Education and Other Social Movements, 5 PerSP. ON POL. 81, 82 (2007) (analyzing the effect of judicial responses to the Civil Rights Movement on subsequent social movements); Meyer \& Whittier, supra note 24 , at 287 (discussing how successful tactical innovations developed by one social movement become part of a "collective action repertoire" upon which subsequent movements draw); Verta Taylor \& Nella Van Dyke, "Get Up, Stand Up": Tactical Repertoires of Social Movements, in The Blackwell Companion To Social Movements 262 (David A. Snow, et al. eds., 2004) (analyzing both the political and cultural outcomes of protest tactics). 
legal mobilization campaign can potentially restructure the legal and cultural environments in which subsequent movements mobilize-shaping various strategies' likelihood for producing success and thus their attractiveness as tools for social change.

The Article proceeds in four Parts. Part I provides a detailed analysis of the early history of same-sex marriage advocacy within the LGBT movement. It discusses an initial radical form of same-sex marriage advocacy that existed among self-identified "gay liberationists" of the 1970s. This radical marriage advocacy was made possible by the low likelihood of gay liberationists actually making legal headway on their demands through the courts or legislatures; in this environment, same-sex marriage activists used litigation as a form of protest-as a way to draw visibility to activists' resistance to heterosexual marriage laws. ${ }^{38}$ As the political climate shifted and LGBT activists grew more conservative in their approach, gay and lesbian civil rights groups pursued more attainable forms of nonmarital relationship recognition, creating increasing legal precedent and cultural visibility for marriage-like gay relationships. Then, in 1992, a case brought by a private attorney in Hawaii generated the first successful challenge to a state ban on same-sex marriage, signaling that marriage had come within same-sex couples' reach..$^{39}$ This Hawaii case ushered in the contemporary era of marriage equality litigation, involving a coordinated effort by mainstream LGBT civil rights organizations to demand constitutional protections for same-sex marriage outright.

Part II takes a direct look at the polyamorous community today. It provides a brief background on the emergence of polyamory as an alternative form of intimate relationships, including its ideological foundations in queer and feminist theory (contrasting polyamory from the better known religious form of nonmonogamy, polygamy). We discuss the ties that exist between the poly and LGBT communities, arguing that despite the minimal direct interaction between poly and LGBT constituencies, poly activists have shown a sense of allegiance to LGBT activism and support for LGBT movement goals. Finally, Part II performs a direct comparison between the contemporary poly community and the early "gay liberation" days of LGBT activism. We highlight the numerous parallels between these communities, including internal values (individualism, antisubordinationist views, antiassimilationist politics) and external political forces (invisibility, "unthinkability" of state relationship recognition), which make these communities ripe for comparative study.

Part III turns to examining the decades-long LGBT legal mobilization for marital and nonmarital relationship recognition, and specifically, how

${ }^{38}$ See generally Michael Boucai, Glorious Precedents: When Gay Marriage Was Radical, 27 Yale J.L. \& Human. 101 (forthcoming 2015) (discussing how early samesex marriage cases pursued radical political agendas).

${ }^{39}$ Baehr v. Lewin, 852 P.2d 44 (Haw. 1993), superseded by constitutional amendment, Haw. Const. art. I, § 23. 
this legal mobilization has shaped the cultural and legal climate in which today's poly community is operating. In general, this analysis suggests that the LGBT legal mobilization may have produced conflicting pressures for contemporary poly activism. While same-sex marriage litigation has created greater traction for legal arguments to expand marriage to poly relationships, it may have simultaneously reinforced cultural stigmas against polyamorous relationships. We propose a set of insights for poly activism in light of this current situation, including the strategies polyamorous activists could borrow (or avoid), the reactions poly activists should expect to face, and the specific lessons they might learn from the LGBT experience.

Part IV then examines the implications of our analysis for legal and sociological theories of social movements. It uses the analysis in Part II as a springboard for theorizing aspects of social movement "spillover," or the "nature of movement-movement influence," 40 that previous work has not yet considered. While it is well known that social movements borrow strategies from one another, less is known about how movements with only weak common activist networks or rarely engage in coalition work come to influence one another. ${ }^{41}$ This Article contributes to this literature by positing a range of structural factors and community conditions that enable the flow of strategies (in this case, relationship recognition strategies) among subordinated social groups. Further, this Article expands on previous socio-legal work examining the numerous "radiating effects" of litigation beyond the direct constituency formally affected by that litigation. ${ }^{42}$ In particular, we suggest that same-sex marriage legal mobilization has raised several extralegal consequences, including changes in cultural expectations and definitions of marriage, intimacy, and the role of law in social change, likely to have spillover effects for poly politics and beyond. We suggest several important directions for future research.

We conclude by reviewing the practical implications of this Article and providing a roadmap of issues, strategies, and challenges that advocates can use in the path toward polyamorous marriages. We think that the struggle for marriage equality could be a step in the path toward the legal recognition of multiple relationships, and that polyamorous activists mobilizing for legal change have much to learn from the marriage equality struggle. However, our approach in this paper is unique in that it does not privilege "winning"

${ }^{40}$ Meyer \& Whittier, supra note 24, at 278.

${ }^{41}$ Although there is evidence that many poly people have sexual relationships with members of the same gender, there is little visible overlap among LGBT and polyamorous political movements. See infra Part II.A. This may be on account of the intentional exclusion of polyamorous activists from LGBT political and community events. See, e.g., Ana Cristina Santos, Intimacy in Times of (De)normalisation: Same-Sex Relational Recognition in Portugal, in Mapping Intimacies: Relations, Exchanges, AfFECTS 209, 218 (Tam Sanger \& Yvette Taylor eds., 2013).

${ }_{42}$ See generally MCCANN, supra note 18 (including broad changes in public policies and social practices in the analysis of legal mobilization); Galanter, supra note 18 (examining the flow of influence outward from courts). 
as the ultimate goal of litigation and marker of success. Rather, our purpose in analyzing the multiple phases of LGBT movement litigation is to offer a variety of strategic models for litigation, which speak to different visions of polyamorous community values and politics. The "impact litigation" model $^{43}$ that defines contemporary same-sex marriage litigation is just one vision of relationship-recognition litigation; we leave it up to polyamorous activists themselves to decide whether to implement such a strategy, or whether to part ways with LGBT activists and forge their own path toward legal acknowledgment of their relationships and families.

A note on terminology is in order before we proceed. Throughout this Article, we have attempted to avoid anachronism by characterizing the LGBT movement by the terms that were most widely used at the time. Accordingly, we refer to the "gay liberation" movement when speaking of activism in the 1970s; to the "gay and lesbian" movement or "queer activists/ organizations" when speaking of activism in the 1980s; and to the "LGBT" movement when speaking of activism from the 1990s onward. When discussing specific communities rather than the movement, we have made every effort to balance our desire for inclusivity with the need for accuracy. Because marriage equality challenges exclusionary marriage laws that primarily burden people of non-heterosexual sexual orientations, we refer to the individuals targeted by marriage equality advances as "LGB" people.

\section{Historical Background on Same-Sex Marriage Activism}

While contemporary same-sex marriage advocacy has been spearheaded by the well-funded, national civil rights groups in the LGBT movement's mainstream, same-sex marriage has historically been on much shakier grounds as a movement objective. This Part provides an account of the radical roots of same-sex marriage activism in the LGBT movement. It traces how the meaning of marriage, and its desirability among LGBT activists, has shifted alongside broader changes in the movement's dominant organizing strategies and political philosophies over the past several decades.

Same-sex marriage was originally championed by locally organized "gay liberationists" of the 1970s as a bold and confrontational assertion of gay empowerment. A farfetched goal at the time, marriage soon became

${ }^{43}$ Impact litigation is a model of social change litigation that involves "[ $t$ ]est cases and planned litigation [which] often seek favorable judicial precedent or judicial orders requiring changes to political or social institutions that redress inequality or relieve marginalized groups from oppressive burdens." Scott Barclay \& Anna-Maria Marshall, Supporting a Cause, Developing a Movement, and Consolidating a Practice: Cause Lawyers and Sexual Orientation Litigation in Vermont, in The Worlds Cause Lawyers Make: Structure and Agency in Legal Practice 171, 174 (Austin Sarat \& Stuart Scheingold eds., 2005) (citing John Kilwein, Still Trying: Cause Lawyering for the Poor and Disadvantaged in Pittsburgh, Pennsylvania, in CAuse Lawyering: Political Commitments and Professional Responsibilities 181 (Austin Sarat \& Stuart Scheingold, eds., 1998)). 
subordinated to more attainable forms of relationship recognition as a new cadre of national gay and lesbian civil rights organizations rose to prominence. As those civil rights organizations directed an increasingly large share of the movement's resources into incremental law reform efforts, some activists on the fringe resurrected the marriage issue, in outright defiance of the mainstream gay and lesbian groups' cautious suppression of the issue. It was not until the mid-1990s when Baehr v. Lewin ${ }^{44}$ proved that same-sex marriage was within the movement's reach that marriage assumed its current position as a centerpiece in the mainstream LGBT movement's agenda.

\section{A. Gay Liberation and Marriage Litigation as Protest}

An unprecedented surge in political activity among gay men and lesbians occurred in the late $1960 \mathrm{~s} .{ }^{45}$ Drawing on the same progressive current that animated leftist organizing in the feminist and black civil rights movements of the day, self-identified "gay liberationists" formed predominantly local, identity-based organizations in cities around the United States. ${ }^{46}$ While gay liberation marked the first time a national common sense of purpose emerged from gay and lesbian political organizing, ${ }^{47}$ gay liberationist groups were far from uniform in their political approaches or in the goals they espoused ${ }^{48}$ Among the diverse goals these groups pursued were: fostering gay pride and empowerment; promoting the equality of LGB individuals vis-àvis straight people; broadening sexual freedom; disrupting binary gender expectations; and ridding society of homophobia and patriarchy. ${ }^{49}$

Gay liberationist politics was also novel in its embrace of confrontational tactics. The predecessors of gay liberation, known as the "homophile" movement, had generally employed a much more conservative approach in attempts to avoid grabbing unwanted publicity. ${ }^{50}$ Gay liberationists, by con-

${ }^{44} 852$ P.2d 44 (Haw. 1993), superseded by constitutional amendment, Haw. Const. art. I, $\S 23$.

${ }^{45}$ The number of gay-identified organizations went from about 50 in 1969 to over 800 in 1973. John D'Emilio, Cycles of Change, Questions of Strategy: The Gay and Lesbian Movement After Fifty Years, in The Politics Of Gay Rights 31, 35 (Craig A. Rimmerman, et al. eds., 2000).

46 Amin Ghaziani, The Dividends of Dissent: How Conflict and Culture Work in Lesbian and Gay Marches on Washington 30 (2008).

${ }^{47}$ See Elizabeth A. Armstrong, From Struggle to Settlement: The Crystallization of a Field of Lesbian/Gay Organizations in San Francisco 1969-1973, in Social Movements And Organization Theory 161, 161, 172 (Gerald Davis et al. eds., 2005).

48 "Indeed, in the early years of gay liberation, the movement suffered from splintered views over what did constitute the primary goal. Was it, as some argued, to gain the same sort of rights enjoyed by heterosexuals . . . ? Or was the goal, as the more radical forces argued, to gain the right to be our different selves (in which case arguments needed to be made in direct support of the sexual interests that were at the core of our difference)?" Patricia Cain, Rainbow Rights: The Role of Lawyers and Courts in the Lesbian and Gay Civil Rights Movement 91-92 (2000).

${ }^{49}$ See Boucai, supra note 38, at 110.

${ }^{50}$ See Mary Bernstein, Identities and Politics: Toward a Historical Understanding of the Lesbian and Gay Movement, 26 Soc. ScI. Hist. 531, 541 (2002). 
trast, defiantly marched in the streets and tried to attract attention through disruptive public action: the Stonewall riots that occurred in June 1969, motivated by a police raid of a New York City bar frequented by LGB and transgender patrons, are representative of this confrontational approach. ${ }^{51} \mathrm{Far}$ from being an isolated event or the first major LGBT political mobilization, the Stonewall riots were one of many fiery public uprisings that emerged in the late 1960s. ${ }^{52}$ Stonewall and similar uprisings were both inspired by and reinforced by the radicalizing trend of gay liberationist politics at the time. ${ }^{53}$

A surge of activism around marriage equality arose from the new gay liberationist politics. ${ }^{54}$ Interestingly, this issue received some national attention outside of concerted gay liberationist activism in the early 1970s, during congressional deliberations regarding the Equal Rights Amendment (ERA). ${ }^{55}$ While the ERA was ostensibly about constitutionalizing antidiscrimination rights for women, ${ }^{56}$ conservatives opposing the amendment used homophobic scare tactics to thwart its passage. Calling it the "Pro-Gay E.R.A.," conservatives argued that ERA legislation at the federal and state levels would force states to endorse same-sex marriage. ${ }^{57}$ Instead of defending same-sex marriage - a reaction that may have drawn attention to the substantial number of lesbians and bisexuals in the feminist movementfeminist supporters of the ERA responded to the attack by insisting that the ERA would not in fact lead to same-sex marriage. ${ }^{58}$ The conservative appeal

${ }^{51}$ Although Stonewall is commonly referred to as the initiating event or event inspiring the "birth" of gay liberation, historical research has demonstrated that Stonewall was just one of several such national riots initiated by LGBT people during this time period. See Elizabeth A. Armstrong \& Suzanna M. Crage, Movements and Memory: The Making of the Stonewall Myth, 71 Am. Soc. Rev. 724, 724-25 (2006) ("The Stonewall riots did not mark the origin of gay liberation. They were not the first time gays fought back against police; nor was the raid at the Stonewall Inn the first to generate political organizing. Other events, however, failed to achieve the mythic stature of Stonewall and indeed have been virtually forgotten." (citations omitted)).

${ }^{52}$ Id. at 736 ("As part of movement radicalization, activists adopted public protest as a strategy. Beginning in the spring of 1965, East Coast Homophile Organizations (ECHO) organized a series of ground-breaking public pickets." (citations omitted)).

${ }^{53}$ See id. at 743 ("[G]ay liberation was a precondition for the recognition of the political potential of the situation at the Stonewall Inn. Without a radical political approach, activists would not have responded by escalating the conflict.").

${ }^{54}$ CAIN, supra note 48, at 158 ("In the early 1970 s, a wave of lesbian and gay activity commenced around the marriage issue.").

${ }_{55}^{5}$ Scott Barclay \& Shauna Fisher, Cause Lawyers in the First Wave of Same-Sex Marriage Litigation, in Cause Lawyers And Social Movements 84, 86 (Austin Sarat \& Stuart A. Scheingold eds., 2006).

${ }^{56}$ The Equal Rights Amendment proposed in 1971-72 would have added to the Constitution gender-specific language guaranteeing sex equality. H.R.J. Res. 208, 92d Cong., 86 Stat. 1523 (1972) ("Equality of rights under the law shall not be denied or abridged by the United States or by any State on account of sex.").

${ }^{57} \mathrm{See}$ R. Claire Snyder, Gay Marriage and Democracy: Equality for All 119 (2006).

${ }^{58}$ See CAIN, supra note 48 , at 257 . It is possible that the feminists making these arguments were disdainful of marriage as an institution and thus deliberately chose not to weigh in on the value of same-sex marriage. Regardless, the message that comes across in their assuaging conservatives' fears of same-sex marriage implicitly accepts the con- 
to homophobia is considered to have "played a role in the failure of the ERA to win ratification of three-fourths of the state legislatures." ${ }^{59}$

While the feminists carefully avoided the same-sex marriage discussion in their ERA advocacy efforts, many gay liberationists confronted the issue head on. ${ }^{60}$ The issue was not a universal priority among the diverse gay liberationist groups. ${ }^{61}$ Some activists rejected marriage as a "rotten, oppressive institution" 62 and called for its abolition, scorning marriage equality advocates for imitating heterosexual relationships. ${ }^{63}$ Others took a more romantic view of the long-term commitment to a same-sex spouse as one more sign on the road to complete liberation. ${ }^{64}$ Still others adopted a third path, which saw same-sex marriage advocacy as a radical goal that advanced goals central to gay liberation, such as embracing pride in homosexuality ${ }^{65}$ and publicly contesting discriminatory institutions. ${ }^{66}$

It is in this context that LGB plaintiffs brought the first same-sex marriage cases to court. These cases, brought in Minnesota, ${ }^{67}$ Kentucky, ${ }^{68}$ and

servative devaluation of LGB relationships. Cf. Clifford J. Rosky, Fear of the Queer Child, 61 BuFf. L. REv. 607, 666-67 (2013) (mapping the fallacies of a progressive empirical response to conservative "slippery slope" arguments, according to which acknowledgment of LGBT relationships will lead to child abuse, as clinging to immutability and as such failing to challenge the normative premise that children are better off straight).

59 William Eskridge, Equality Practice: Civil Unions and the Future of Gay Rights 8 (2002) [hereinafter Eskridge, Equality PRActice].

${ }^{60}$ Michael Boucai's research suggests that gay liberationists focused on marriage for reasons unrelated to the ERA. Boucai's interviews with plaintiffs in the early 1970s marriage cases suggest that these activists were generally seeking publicity and promoting gay and lesbian pride; the activists did not cite ERA-related rhetoric as a motivation for their marriage-related activism. See Boucai, supra note 38, at 150.

${ }^{61}$ Then again, the movement at the time was so decentralized that no issue likely could be considered universal. Moira Kenney, Mapping Gay L.A.: The Intersection of Place ANd Politics 83 (2001) (describing prominent gay liberation organization the Gay Liberation Front as having a "hallmark decentralized street-based structure").

${ }^{62}$ Michael J. Klarman, From the Closet to the Altar: Courts, Backlash, and the Struggle for Same-Sex Marriage 22 (2013) (“An early gay manifesto denounced traditional marriage as a 'rotten, oppressive institution' that is 'fraught with role playing." ').

${ }^{63}$ CAIN, supra note 48, at 159 (one Seattle-based activist who prepared a position statement on marriage for the ACLU of Washington in 1970 "explain[ed] the discriminatory effect of marriage on lesbians and gay men and call[ed] for the total abolition of marriage"); Lee Walzer, Gay Rights on Trial: A Reference Handbook 129-30 (2002).

${ }^{64}$ CAIN, supra note 48 , at 159 . The fact that there were "thousands of couples who sought in the wake of Stonewall to solemnize their relationships in private ceremonies," Boucai, supra note 38 , at 108, suggests that there were many LGB people at the time who were in this camp.

${ }^{65}$ Boucai, supra note 38 , at 162 (arguing that marriage advocacy was "fervently embraced by the gay liberation movement, that 'gay is good'-even 'to the degree of being sacred" ").

${ }^{66}$ Id. at 169 (marriage advocates of the 1970s sent the message that "there's other [LGB] people like you, and we're fighting back").

${ }^{67}$ Baker v. Nelson, 191 N.W.2d 185 (Minn. 1971).

${ }^{68}$ Jones v. Hallahan, 501 S.W.2d 588 (Ky. 1973). 
Washington ${ }^{69}$ raised three central constitutional arguments that have remained essential in same-sex marriage litigation to this day: ${ }^{70}$ first, that same-sex marriage prohibitions constituted sex-based discrimination (violating plaintiffs' rights to equal protection); second, that same-sex marriage prohibitions constituted sexual orientation discrimination and that sexual orientation is a presumptively unconstitutional "suspect classification" (again violating plaintiffs' rights to equal protection); and third, that prohibiting plaintiffs from marrying a same-sex partner denied a fundamental right (violating plaintiffs' constitutional privacy interests). ${ }^{71}$

These early same-sex marriage cases were clearly a product of their time in how they were pursued. The plaintiffs filed individually with private attorneys, without being represented by a major LGBT legal organization. ${ }^{72}$ This was partly because only a handful of lesbian and gay public interest law firms existed in the early 1970 s when these cases were being litigated ${ }^{73}$ and those law firms that did exist at the time limited their functions largely to providing relief to LGB people whose rights had been violated. ${ }^{74}$ The fact that the early marriage plaintiffs filed claims with private attorneys also reflects the decentralized politics of "gay liberation." While most of the plaintiffs in those cases belonged to local gay liberationist groups, ${ }^{75}$ none of the litigation was associated with those organizations or the larger movement community. ${ }^{76}$

On one hand, these early marriage cases demonstrate a serious engagement with the idea of legal protections for same-sex marriage. The attorneys in these cases creatively deployed the most compelling legal arguments

${ }^{69}$ Singer v. Hara, 522 P.2d 1187 (Wash. Ct. App. 1974).

${ }^{70}$ Boucai, supra note 38, at 149 (stating that the Baker, Jones, and Singer cases presented "[e]ach of the most prominent arguments in today's gay marriage arsenal").

${ }^{71} \mathrm{Id}$. Each of these arguments is discussed in detail in Part III.

${ }^{72}$ See generally id. (providing a detailed description of the three early-1970s marriage cases).

${ }^{73}$ CAIN, supra note 48, at 57 ("In the early 1970s, two public interest law firms were launched . . . Lambda Legal . . . [and] Equal Rights Advocates.”).

${ }^{74} I d$. at 59 ("At first, litigation efforts on behalf of gay men and lesbians were primarily reactive, occurring in cases in which individuals were forced to defend the rights that had been taken from them. Some time would pass before the lawyers for the movement would become sufficiently organized to be proactive.").

${ }^{75}$ One of the plaintiffs in Baker v. Nelson, 191 N.W.2d 185 (Minn. 1971), belonged to the University of Minnesota gay student group "FREE." Boucai, supra note 38, at 113. The plaintiffs in Singer v. Hara, 522 P.2d 1187 (Wash. Ct. App. 1974), belonged to the Seattle Gay Alliance (SGA). Boucai, supra note 38, at 143-44. The plaintiffs in Jones v. Hallahan, 501 S.W.2d 588 (Ky. 1973), belonged to the Gay Liberation Front (GLF). Boucai, supra note 38 , at 135.

${ }^{76}$ Nancy D. Polikoff, Beyond (Straight and Gay) Marriage 47-48 (2008) (discussing the Minnesota and Washington cases). The idea for the case came from "a reputation-hunting criminal lawyer named Stuart Lyon, who had heard about the Minnesota lawsuit and wanted a 'controversial case' of his own." Boucai, supra note 38, at 132. Lyon located the plaintiffs through a mutual connection and they "up and went to the marriage license bureau." Id. at 132-33. 
available. ${ }^{77}$ Yet on the other hand, the plaintiffs in these cases had no genuine expectation that they would succeed. In the early 1970s, the idea of same-sex marriage was "unthinkable" to a degree that is difficult to conceptualize. ${ }^{78}$ Defeat was so certain that one of the Washington plaintiffs, in a later interview, recalled his involvement in the case as a "political ploy." 79 The Eighth Circuit similarly referred to the Minnesota marriage suit as an "antic." 80

Given the low prospects for success in these early marriage cases, why did activists pursue those cases in the first place? Michael Boucai's in-depth examination of these cases has shown that a large motivation was to send a political message - to promote goals such as fostering pride and gay visibility ${ }^{81}$ which resonated with radical gay liberationist ideals. ${ }^{82}$ Accordingly, the strategy reflects less of the standard emphasis on winning, which dominates impact models of social change litigation today. Instead, the model that drove the gay liberationist marriage equality cases was premised on cultural gain rather than formal legal reform. ${ }^{83}$

Claiming a right to same-sex marriage in the early 1970s also evoked such shock and revulsion from the heterosexual mainstream that the early marriage cases resonated with the radical politics of gay liberation. These cases were confrontational and disruptive, showing a clear refusal to remain quietly closeted or to patiently wait for society to come around to accepting gay men and lesbians. In addition, demanding marriage rights in a context where plaintiffs could expect to be summarily dismissed sent more of a message regarding the injustice of marriage than a commitment to entering the institution. Indeed, framing marriage as an unjust institution resonated the idea, expressed by one of the Singer plaintiffs, that he thought marriage was "wrong" and "oppressive," and that he "would just as soon abolish marriage" as enter into it. ${ }^{84}$ Thus, although subsequent scholarly work has inter-

${ }^{77}$ As an example of the attorneys' creativity, all three of the attorneys in these cases raised the claim that prohibitions on same-sex marriage violated the Eighth Amendment-a claim that "today's litigators would not dream of arguing." Id. at 151.

${ }^{78} \mathrm{Id}$. at 159 .

${ }^{79} \mathrm{Id}$. at 158 .

${ }^{80}$ CAIN, supra note 48 , at 161 .

${ }^{81}$ Boucai, supra note 38, at 125 (describing core liberationist principles: "[an] insistence on gay pride and the virtue of gay love; [a] deep commitment to feminism; [a] heterogeneous critique of marriage and of the nuclear family; and [a] pursuit of visibility through audacious and often theatrical disruption").

${ }_{82}$ The present Article seeks to build upon the counter-narrative that Boucai's work establishes to the traditional, dualist account that pits marriage equality advocacy against gay liberation radicalism. For related work building on this topic, see Douglas NeJaime, Before Marriage: The Unexplored History of Nonmarital Recognition and Its Relationship to Marriage, 102 CALIF. L. Rev. 87, 91-92 (2014) [hereinafter NeJaime, Before Marriage].

${ }^{83}$ Cf. Douglas NeJaime, Winning Through Losing, 96 IowA L. Rev. 941, 977 (2011) (describing how one Christian Right organization litigates school-programming cases with little chances of success because the cases enable cultural movement goals such as creating visibility for core movement issues).

${ }^{84}$ Boucai, supra note 38, at 107, 180. 
preted these cases as representing a romantic, rosy-eyed view of marriage,,$^{85}$ it is more likely that the meaning that was derived from these cases at the time-and, as Boucai's work shows, the meaning that the plaintiffs themselves ascribed to the cases ${ }^{86}$-is that the early marriage plaintiffs were using litigation as a form of protest against unjust, discriminatory marriage laws. ${ }^{87}$

Why were these early arguments demanding marriage equality so radical, such that they were "all but laughed out of court"? ${ }^{88}$ The historical context of these cases is relevant in determining their meaning and interpretation at the time they were pursued. It is not that marriage laws were impermeable to politically motivated reform. Feminists and civil rights activists had been challenging anti-miscegenation laws and marriage laws denying women equal property rights for decades by this time, with several landmark successes, showing that marriage was malleable enough to bend to political pressure. ${ }^{89}$ The answer likely has more to do with the cultural framing of homosexuality, which was mired in notions of shame and deviance, not pride and public visibility.$^{90}$ LGB people as a social group had just begun to penetrate the public's consciousness. The widespread media coverage of the initial marriage lawsuits may have been the first time that the idea of gay relationships entered many people's scope of vision. Thus, despite the viabil-

${ }^{85}$ See e .g., William N. Eskridge JR. \& Darren R. Spedale, Gay Marriage: for Better or for Worse?: What We've Learned from the Evidence 251 (2006) (arguing that the plaintiffs in Minnesota's early same-sex marriage case "hold [marriage] up as a holy grail that lesbian and gay couples should strive to attain" and that "[ $t]$ hey want the romanticism of traditional marriage to touch and transform the lives of gays in America").

${ }^{86}$ See generally Boucai, supra note 38.

${ }^{87}$ Cf. Oneida Meranto, Litigation as Rebellion, in Social Movements And American Political Institutions 216, 227 (A. Costain \& A. McFarland eds., 1998) (discussing litigation as a form of protest in the context of Indian tribal rights); see also CAIN, supra note 48, at 259 (quoting a Hawaii newspaper as stating that " 25 gay couples are expected to file for marriage licenses to protest state ban on same-sex marriages").

${ }^{88}$ Ellen Ann Andersen, Out of the Closets and into the Courts: Legal Opportunity Structure and Gay Rights Litigation 206 (2008).

${ }^{89}$ The National Association for the Advancement of Colored People (NAACP) began challenging anti-miscegenation laws and policies as early as World War II. See Perez v. Lippold, 198 P.2d 17, 22-25 (Cal. 1948) (striking down a ban on interracial marriage); Rachel F. Moran, Loving and the Legacy of Unintended Consequences, 2007 WIS. L. Rev. 239, 251 (2007). Feminists advocated to reform marriage statutes that treated women unequally to men with respect to property ownership and inheritance since the nineteenth century. See Joan C. Williams, Reshaping the Work-Family Debate 115 (2010). The Supreme Court dealt the feminist movement a series of victories in this area starting in the early 1970s. See Califano v. Goldfarb, 430 U.S. 199, 202 (1977) (invalidating gender-based distinctions in survivors' benefits in the Social Security Act); Weinberger v. Wiesenfeld, 420 U.S. 636, 638-39 (1975) (same); Reed v. Reed, 404 U.S. 71, 74 (1971) (invalidating an Idaho statute giving preference to men when appointing administrators of estates).

${ }^{90}$ See Jordan Blair Woods, The Birth of Modern Criminology and Gendered Constructions of Homosexual Criminal Identity, 62 J. Homosexuality 131, 132 (2015) ("Prior to the 1970s, LGBTQ people in Western countries were commonly labeled as criminals, psychopaths, sinners, and perverts." (citation omitted)). 
ity of same-sex marriage as a concept whose recognition under law would not entail much of a doctrinal stretch, the cultural climate in which the early marriage cases were raised infused those claims with a sense of radicalism.

\section{B. Gay Rights Advocacy Puts Marriage on the Fringe}

By the 1980s, LGBT activism had undergone major changes that left the marriage issue in decline. As many commentators have noted, the dominant political logic that defined LGBT activism shifted from the progressive and radical strain of gay liberation politics to a "gay rights" model defined by traditional civil rights strategies such as litigation and lobbying. ${ }^{91}$ In this environment, the radical marriage activism of the seventies "languished in a generational purgatory." 92

A standard explanation given for this lull in marriage equality activism during the 1980s is that there was too much ideological opposition to marriage coming from within the movement to legitimately prioritize the issue. ${ }^{93}$ Yet civil rights groups frequently pursue issues that are not universally supported by their constituencies. ${ }^{94}$ Plus, as the early marriage cases show, the prospects for actually winning marriage rights at this time were so low that demands for marriage equality were more meaningful for their radical messaging effects-promoting gay visibility and protesting the discriminatory effects of marriage-than for their ability to bring same-sex couples within the institution's fold. ${ }^{95}$

Increasing evidence suggests that the reason same-sex marriage advocacy declined in the 1980s was not that gay and lesbian activists were too radical for marriage, but rather that marriage was too radical for them. ${ }^{96}$ Lesbian and gay activists faced an onslaught of negative developments, most notably the onset of HIV/AIDS and the mobilization of a powerful antigay countermovement, which set activists back significantly and put many of

${ }^{91}$ Armstrong, supra note 47, at 161 ("Many scholars have remarked upon the transformation of gay liberation from a radical movement into one focused on identity building and gay rights." (citations omitted)).

${ }^{92}$ William N. Eskridge, Jr., The Case for Same-sex Marriage: From Sexual Liberty to Civilized Commitment 57 (1996). See also Walzer, supra note 63, at 132 ("The failure of these early cases, along with the ideology professed by some segments of the gay and lesbian community, led to a long lull in the effort to win the right to marry.").

${ }_{93}$ NeJaime, Before Marriage, supra note 82, at 108.

${ }^{94}$ See generally Derrick A. Bell, Jr., Serving Two Masters: Integration Ideals and Client Interests in School Desegregation Litigation, 85 YALE L.J. 470 (1976) (examining how civil rights attorneys' decisions and priorities often departed from those of their clients in school desegregation litigation); Leonore F. Carpenter, Getting Queer Priorities Straight: How Direct Legal Services Can Democratize Issue Prioritization in the LGBT Rights Movement, 17 U. PA. J.L. \& Soc. Change 108 (2014) (arguing that LGBT civil rights organizations' decision-making structures generate litigation priorities that clash with the priorities of many in the LGBT community).

${ }^{95}$ See supra Part I.A.

${ }^{96}$ KLARMAN, supra note 62, at 22 ("This was a decade of incremental progress for gay rights, and gay marriage was a radical reform, not an incremental one."). 
them on a cautious and defensive track. ${ }^{97}$ In this more conservative political climate, the shock value of marriage (which had driven gay liberationists toward the marriage issue) may have repelled the gay rights groups. ${ }^{98} \mathrm{In}$ addition, the organizational changes that accompanied the new LGB civil rights approach discouraged activists from pursuing risky issues like marriage. Unlike the small and fragmented set of gay liberationist organizations of the 1970s, the lesbian and gay civil rights organizations of the 1980s were large and bureaucratic, and they invested their significant share of the movement resources into developing long-term national strategic agendas ${ }^{99}$ With this level of organizational weight being thrown into law reform strategies, much more was at stake in the highly likely event of litigation loss in the marriage equality context.

Interviews with lawyers involved in lesbian and gay rights litigation at the time support the conclusion that caution and conservatism rather than radical politics fueled litigators' early decisions to avoid marriage cases. ${ }^{100} \mathrm{In}$ 1989, attorneys from one of the largest lesbian and gay rights legal organizations of the day, the National Gay Rights Advocates (NGRA) (which disbanded in 1993), had strongly considered representing a gay couple in a state-court challenge to Alaska's prohibition on same-sex marriage. ${ }^{101}$ The attorneys at NGRA, who considered their organization to be more on the "cutting edge" than most of the lesbian and gay legal organizations of the day, ${ }^{102}$ had even developed a litigation strategy ${ }^{103}$ and were ready to move forward. However, when they presented the idea at a litigators' roundtable (a regular meeting of the nation's LGBT legal organizations), the other attorneys in attendance expressed vehement opposition. ${ }^{104}$ The reasons for the resistance had to do with the perceived inability of marriage litigation to succeed in court at that time. ${ }^{105}$ As one NGRA attorney recalled:

${ }^{97} C f$. Tina Fetner, How the Religious Right Shaped Lesbian and Gay ActivISM 45 (2008).

${ }^{98}$ See Klarman, supra note 62, at 22.

99 Fetner, supra note 97, at 44.

${ }^{100}$ For the methodology used in these interviews, see Gwendolyn M. Leachman, From Protest to Perry: How Litigation Shaped the LGBT Movement's Agenda, 47 U.C. DAvis L. Rev. 1667, 1722 (2014).

${ }^{101}$ Minutes, NGRA, Minutes of the NGRA Litigation Committee (Jan. 19, 1989) (copy on file with second author).

${ }^{102}$ Interview with Anonymous, NGRA, in L.A., Cal. (Sept. 17, 2012) (transcript on file with second author).

${ }^{103}$ Minutes, NGRA, supra note 101 ("This suit would be based on the right to privacy and right to equal protection of the law as guaranteed by the Alaska Constitution."); Interview with Anonymous, NGRA, supra note 102 ("I remember we developed a [marriage] case in Alaska, sort of looking at the different courts, at which ones were more likely to get a positive result down the road.").

${ }^{104}$ Interview with Anonymous, NGRA, supra note 102 (reporting other attorneys "wanting us to hold back on that" and "telling us not to move in that direction").

${ }^{105}$ Id. (saying that the other LGB legal organizations "thought it wasn't the right time" for marriage). 
I think that was one of the critiques about NGRA, that we would do stuff like pushing marriage in Alaska . . . that you won't get anywhere with that. But it's like, you'll get there because you're advancing a social agenda. You know? The law is in service of social change - that is the whole purpose of it. ${ }^{106}$

These comments suggest that the interviewed NGRA attorney had a view of litigation that was much more in line with the "litigation as protest" model of the 1970s. The flak that he and other NGRA attorneys received for pursuing same-sex marriage can be attributed to the other gay rights attorneys' "concern[s] about making bad caselaw." 107 Other individuals attempting to pursue same-sex marriage litigation by enlisting the help of private attorneys faced similar blowback. The plaintiff in a Washington, D.C. marriage lawsuit filed in 1991 reported receiving criticism from gay and lesbian civil rights lawyers (whom one plaintiff called "self-appointed gay legal czars") fearful that the case would set bad precedent. ${ }^{108}$ These stories suggest that caution, rather than radicalism, was the primary force driving the major gay and lesbian civil rights organizations' resistance to marriage litigation in the late 1980 s and early 1990 s. ${ }^{109}$

Over time, increasing numbers of activists became frustrated with the leading gay and lesbian civil rights groups' incremental law-reform strategy. A newly minted brand of activists, who called themselves "queer" (rather than "gay and lesbian"), began to organize a new political agenda in outright opposition to the mainstream movement's civil rights groups. ${ }^{110}$ Queer groups modeled themselves on their radical predecessors in the gay liberation movement. Their members used confrontational, creative direct action, aimed at transforming the dominant sexual culture to affirmatively embrace not only homosexuality, but other non-normative sexual practices and forms of intimacy as well. ${ }^{111}$

${ }^{106} I d$.

${ }^{107} \mathrm{Id}$

${ }^{108}$ Craig R. Dean, Demanding Gay Marriage; One Gay Man's Account of the Struggle to Have his Union Recognized, 19 Gay Community News 7, 7 (1991).

${ }^{109}$ This research, like previous work by Douglas NeJaime, calls into question the accuracy of the typical scholarly narrative, which holds that LGBT movement attorneys initially avoided marriage arguments for ideological reasons (e.g., rather than strategic ones). Cf. NeJaime, Before Marriage, supra note 82, at 91 ("This Article challenges the assumptions that structure the ongoing scholarly debate over LGBT advocacy and marriage. By revisiting the earlier era on which today's critical assessments often rest, it uncovers marriage's centrality even before marriage became a formal part of the movement's agenda.").

${ }^{110}$ See Joshua Gamson, Must Identity Movements Self-Destruct? A Queer Dilemma, 42 Soc. Probs. 390, 394 (1995) (describing queer politics as a "rejection of civil rights strategies "in favor of . . . anti-assimilationist politics" (quoting Arlene Stein \& Ken Plummer, "I Can't Even Think Straight": "Queer" Theory and the Missing Sexual Revolution in Sociology, 12 Soc. THEORY 178, 182 (1994))).

${ }^{111} I d$. (stating that queer politics involve a "willingness to interrogate areas which would not normally be seen as the terrain of sexuality" (quoting Stein \& Plummer, supra note 110 , at 182)). 
The queer groups on the fringe of the lesbian and gay movement were the first to revive same-sex marriage in an organized fashion. As early as $1989,{ }^{112}$ queers around the country began staging "marry-in" demonstrations, ${ }^{113}$ during which same-sex couples would solemnize marriage vows (although oftentimes not so solemnly ${ }^{114}$ ) in public protest over their exclusion from state marriage laws. One "marry-in" staged by the San Francisco chapter of Queer Nation (one of the major protest groups to emerge in cities across the United States in the late 1980s) provides a feel for the tenor of these marriage protests. In 1990, queer protestors entered the city's marriage bureau in pairs and created a spectacle when the clerks refused to issue them marriage licenses_-kissing at the window, refusing to leave, even calling the clerks "accomplices to murder." 115 They then engaged in a mass mock wedding ceremony at city hall wearing campy "wedding drag" attire. ${ }^{116}$

As this depiction suggests, these queer "marry-ins" involved far more revelry than reverence-suggesting that queers, like gay liberationists, were fully prepared for their demands to fall on deaf ears. The purpose of these protests, however, was not to actually get married; it was rather to send a message about the injustice of discriminatory marriage laws and how those laws stigmatized and subordinated LGB people. Indeed, even though the queer marry-in participants were demanding marriage rights, the goal for at least some of the protestors seems to have been to create a mockery of marriage. Archival sources documenting these protests suggest that many, if not most, of the members of the queer groups staging the protest were critical or outright opposed to marriage. ${ }^{117}$ The Chicago Queer Nation chapter acknowledged that many of its members "personally do not endorse the institution of marriage." 118 Queer Nation's general pro-marriage position papers referred to marriage as "an institution we all agree oppresses us" 119 and denounced the patriarchal roots of marriage.

112 Video footage of a 1989 ACT UP marriage protest in New York City is archived at http://perma.cc/XGV8-2H93.

${ }_{113}$ Memorandum, Queer Nation/Chicago Advocates Legal Rights For Same-Sex Couples: Queer Nation Marry-In, Queer Nation (on file with second author).

${ }^{114}$ See Pamphlet, You Are Cordially Invited to a Queer Wedding, Queer Nation (Sept. 10, 1990) (on file with second author) (encouraging marry-in protestors at City Hall to don "[s]igns, placards, and post-modern wedding drag").

${ }^{115}$ See Pamphlet, What to Do at a Queer "Marry-In," Queer Nation (1990) (on file with second author).

${ }^{116}$ See Pamphlet, You Are Cordially Invited to a Queer Wedding, supra note 114.

${ }^{117}$ See Memorandum, Queer Nation/Chicago Advocates Legal Rights for Same Sex Couples, supra note 113 (advertising a Queer Nation marry-in and stating that the group's members "personally do not endorse the institution of marriage"); Pamphlet, What to do at a Queer "Marry-In," supra note 115; Open Letter, John Mayflower, Legalized SameSex Marriage, Queer Nation (Jan. 23, 1991) (copy on file with second author) (stating that "[t]he question most vocally raised today about marriage is the notion that it is patriarchal i.e., an institution created by man to capture and enslave women").

${ }^{118}$ Memorandum, Queer Nation/Chicago Advocates Legal Rights for Same Sex Couples, supra note 113 .

${ }^{119}$ Pamphlet, What to do at a Queer "Marry-In," supra note 115. 
Remarkably absent from the queer groups' writings on marriage was the sense that members were particularly torn about their organization's focus on marriage. Instead, the documents these groups produced suggest that members did not see demanding marriage rights as discordant with opposing marriage. For example, one flyer denounced marriage and encouraged members to participate in demanding marriage rights in the same breath: "Those who have problems with marriage in general can still express their outrage at an institution which we all agree oppresses us, whether by omission or commission. What a better place to hold a kiss-in and demand that the privileges associated with marriage be extended to everyone." ${ }^{120}$ This passage again suggests that demanding marriage was aimed less at endorsing marriage and more at expressing queers' "outrage" at marriage and shocking the public.

The queer marriage protest strategy exemplifies how the legal and cultural context of marriage-related political action can thoroughly transform the meaning and interpretation of that action. Early marriage advocacy was able to send a marriage-destabilizing message precisely because the idea of same-sex marriage held no legal or cultural resonance at the time. The inaccessibility of marriage - the fact that LGB couples' demands for marriage would unquestionably be summarily denied - is what enabled both the early gay liberation activists and later queer activists to construct a radical samesex marriage campaign, using litigation to send a message of marriage's institutional illegitimacy.

\section{Marriage Equality Enters the Mainstream}

While many in the mainstream LGBT civil rights groups of the late 1980s and early 1990s actively discouraged same-sex marriage litigation, ${ }^{121}$ some "rogue" marriage cases represented by private attorneys arose at this time nonetheless. ${ }^{122}$ This section turns to examining how a victory in one of those same-sex marriage cases - a victory made possible in part by the mainstream groups' efforts to secure nonmarital recognition of marriage-like relationships between same-sex couples-transformed marriage equality from a radical concept to a tangible movement goal. Once marriage was within reach, mainstream LGBT organizations shifted focus, coming to prioritize the pursuit of same-sex marriage rights that has remained a central priority to this day.

${ }^{120} I d$.

${ }^{121}$ See Andersen, supra note 88, at 177.

${ }^{122}$ For example, in March of 1990, gay couples in Honolulu began preparations for marriage equality litigation. Robert W. Peterson, Gay Marriage Query Becomes a Sticky Issue for Hawaii ACLU Chapter, AdvocATE, Sept. 25, 1990, at 27. In late 1990, a gay couple filed another marriage case in Washington D.C. Patrice Gaines-Carter, Legal Snag Keeps Gays from Tying the Knot: Couple Denied Marriage License Sues D.C., Wash. Post, Dec. 6, 1990, at C5. 
Although explicit advocacy for same-sex marriage remained taboo among mainstream gay and lesbian civil rights groups in the early 1990s, attaining legal recognition of and benefits for same-sex relationships was a central priority. ${ }^{123}$ The U.S. Supreme Court decision Bowers v. Hardwick, ${ }^{124}$ which upheld the constitutionality of state laws criminalizing sexual intimacy between gay adults, ${ }^{125}$ derailed much of these organizations' impact litigation strategies in the federal courts, ${ }^{126}$ prompting large-scale shifts in legal strategy. ${ }^{127}$ Among these shifts was the decision to prioritize the issue of relationship recognition. ${ }^{128}$ Gay and lesbian civil rights groups sought legal recognition for LGB couples in areas from family law, to insurance benefits, to employment discrimination. A main priority targeted by the National Center for Lesbian Rights (formerly Lesbian Rights Project), for example, was custody and visitation rights for lesbian mothers who were denied access to their children after being separated from the children's biological mothers. ${ }^{129}$ Another priority was securing insurance benefits for same-sex partners. ${ }^{130}$ NGRA pursued cases in which partners were essentially living like married couples but were refused insurance benefits such as discounts granted to married people, access to joint "umbrella" liability policies (saving them nearly half the cost of separate policies), or access to employer-provided health insurance benefits for the same-sex partners of insured LGB employees. ${ }^{131}$

While the lesbian and gay rights organizations that pursued these nonmarital relationship recognition cases may have considered those cases a "safe" alternative to marriage litigation, their efforts-in the court of public opinion at least — tended to be construed as advancing the cause of same-sex

${ }^{123}$ See Andersen, supra note 88, at 39; CAIn, supra note 48, at 169-72.

124478 U.S. 186 (1986).

${ }^{125} \mathrm{Id}$. at 196.

${ }^{126}$ Joseph Landau, Ripple Effect, New RePUBLIC (June 23, 2003), http://www.newre public.com/article/ripple-effect, archived at http://perma.cc/R6A8-YHUS.

${ }^{127}$ Cummings \& NeJaime, supra note 7, at 1249.

${ }^{128}$ Unpublished Panel Notes, Anne Goldstein, Nan D. Hunter \& Jay M. Kohorn, Where After Hardwick?, Lavender Law (Nov. 12, 1988) (on file with second author) (discussing the need to "refocus on the family" after Bowers v. Hardwick).

${ }^{129}$ Lesbian Rights Project, Fact Sheet ("Founded in 1977, the Lesbian Rights Project began by specializing in custody and related family issues. Since then, LRP has counseled thousands of lesbian mothers and gay fathers through their legal struggles to maintain and regain custody of their children.") (on file with second author).

${ }^{130}$ See Frederick Hertz \& Emily Doskow, Making It Legal: A Guide to SameSex Marriage, Domestic Partnerships \& Civil Unions 10-11 (2009) (discussing the campaign to obtain insurance benefits for same-sex couples in San Francisco in the 1980 s).

${ }^{131}$ See, e.g., Gay Couples Charged Double for House Insurance, NGRA NewsLETTER (Nat'l Gay Rights Advocates), Winter 1988-1989, at 2 (on file with second author) ("Boyce Hinman and Larry Beaty have lived together as family partners for 14 years in Sacramento. They own a home together, have a joint bank account, and are each other's primary beneficiaries in their wills and life insurance policies. When they applied for additional home liability coverage, with Farmers Insurance Company, they were told their premium would be $\$ 260$ — instead of the $\$ 130$ they would be charged if they were married."). 
marriage. ${ }^{132}$ As work by Douglas NeJaime has shown, even as LGBT litigators pursued alternatives to marriage, they often used marriage as a key reference point. ${ }^{133}$ Attorneys would often talk about their nonmarital cases in marriage-like terms, stressing things like emotional and economic interdependence, mutual support, intimacy, and length of time together. ${ }^{134}$ In NeJaime's case study of domestic partnership work in California in the 1980s and 1990s, NeJaime shows that:

[T]o achieve nonmarital recognition, advocates appealed to marriage's conventions, pointed to the unique exclusion of same-sex couples from marriage, and stressed same-sex couples' commonality with married couples. In building domestic partnership, they emphasized marital norms-such as adult romantic affiliation, mutual emotional commitment, and economic interdependencecapable of including same-sex couples. By challenging marriage's primacy while arguing for recognition in terms defined by marital norms, advocates contested, accepted, and ultimately shaped the institution of marriage while simultaneously portraying same-sex relationships as marriage-like. ${ }^{135}$

Newspaper articles covering nonmarital relationship recognition cases also framed those cases as relating to marriage, noting how LGB people needed to compensate for the fact that the "law does not recognize any form of gay marriage." 136 For example, one 1990 article in the New York Times covering the increasing number of custody cases involving LGB parents described the origins of the phenomenon as follows:

As homosexual men and women become more public, and an increasing number of lesbian couples choose to rear children, they are taking their private problems to court. Increasingly, judges face the daunting task of handling what amount to divorces involving people who cannot legally marry. They must address contracts disputes, the division of property and businesses, and support payments. ${ }^{137}$

Perhaps taking its cue from the attorneys in the case, the Times article reflects a dominant tendency in the mainstream media to frame nonmarital relationship recognition cases as being necessitated by out-of-date marriage

${ }^{132}$ NeJaime, Before Marriage, supra note 82, at 161 ("Both supportive and hostile responses filtered LGBT claims through the lens of marriage, and such responses often redirected advocates' energy and constrained potentially more transformative visions.").

${ }^{133} \mathrm{Id}$. at 113.

${ }^{134} \mathrm{Id}$.

${ }^{135} \mathrm{Id}$.

${ }^{136}$ Anne Stroock, Gay "Divorces" Complicated by Lack of Laws, S.F. CHron., May 14, 1990, at A4.

${ }^{137}$ David Margolick, Child Custody Cases Test Frontiers of Family Law, N.Y. Times, July 4, 1990, at 1 . 
laws that arbitrarily excluded otherwise marriage-like same-sex relationships. Whatever the "true" motivations that gay and lesbian civil rights attorneys might have intended in pursuing these cases, the interpretation promoted by the press was that the problem was the narrowness of marriage_-suggesting that marriage should be extended (not abolished). ${ }^{138}$ Thus, while lesbian and gay litigation groups may have pursued nonmarital relationship recognition to avoid creating too much of a splash, their efforts in this area ultimately worked in tandem with the more radical, explicit marriage activism by queer protest groups (and the gay liberationists before them) to awaken the heterosexual public's consciousness to the idea of samesex marriage. ${ }^{139}$

It was in this setting - following years of nonmarital relationship recognition advocacy and radical same-sex marriage "protests" in the courts and streets-that same-sex couples received their first courtroom victory for marriage equality. ${ }^{140}$ In 1991, gay couples in Hawaii (represented by private counsel ${ }^{141}$ ) challenged on state constitutional grounds the state's refusal to grant them a marriage license. ${ }^{142}$ While a circuit court initially dismissed these plaintiffs' complaint for failing to state a cognizable claim, ${ }^{143}$ the Hawaii Supreme Court later vacated the circuit court's decision, holding that denying same-sex couples the right to marry violated the state constitution's equal protection clause. ${ }^{144}$ The Hawaii Supreme Court rejected as "circular" the state's argument - an argument that had been readily accepted by previous state courts in Minnesota and Washington ${ }^{145}$ - that the traditional, dic-

${ }^{138}$ Without ascribing a specific motivation to the attorneys pursuing the nonmarital relationship recognition efforts, there is evidence to suggest that marriage did in fact figure strongly in the LGB attorneys' framing of these cases. See generally NeJaime, Before Marriage, supra note 82 (examining how advocates for nonmarital relationship recognition framed their claims in marriage-like terms).

${ }_{139} \mathrm{Cf}$. Barclay \& Fisher, supra note 55, at 90-91 (arguing that the early marriage cases signaled to the public that the "sexual configuration associated with marriage was now contested and that the imposed sexual hegemony was no longer simply accepted as natural").

${ }^{140}$ Baehr v. Lewin, 852 P.2d 44, 59-63 (Haw. 1993), superseded by constitutional amendment, Haw. Const. art. I, § 23 (holding that a Hawaii statute that expressly discriminates against same-sex marriage constitutes sex discrimination under the Hawaii Constitution and is subject to strict scrutiny).

${ }^{141}$ The couples were represented by ex-ACLU attorney Dan Foley. ANDERsEn, supra note 88, at 178. "Foley approached both Lambda and the ACLU for assistance in the case, but they both declined the invitation to become cocounsel [sic]." Id.

${ }^{142}$ Baehr, 852 P.2d at 48-49.

${ }^{143} \mathrm{Id}$. at 52 .

${ }^{144}$ See id. at 59-60 (noting that the Hawaii Constitution is "more elaborate" than the Federal Constitution and that "by its plain language, the Hawaii Constitution prohibits state-sanctioned discrimination against any person in the exercise of his or her civil rights on the basis of sex").

${ }^{145}$ Baker v. Nelson, 191 N.W.2d 185 (Minn. 1971); Singer v. Hara, 522 P.2d 1187 (Wash. Ct. App. 1974). These earlier decisions upheld state prohibitions on same-sex marriage through little more than a recital of the dictionary definition of marriage as a union between two opposite-sex individuals. 
tionary definition of marriage as between individuals of the opposite sex forbade same-sex couples from marrying. ${ }^{146}$

The Baehr decision became the focus of massive public attention. ${ }^{147}$ In the years since the same-sex marriage cases of the early 1970s, LGBT people had become much more publicly visible. The HIV/AIDS epidemic put gay men on the nightly news and made LGB people the topic of political discussion and public commentary, ${ }^{148}$ priming public interest in same-sex marriage. The "in your face" approach of queer activism in the early 1990s also demanded public attention. While the increasing visibility of LGB people may have been disconcerting for many straight people and alarming for social conservatives, little concerted antigay organizing took place until after Baehr. ${ }^{149}$ Conservatives framed the impact of the Hawaii decision broadly, noting that states across the nation would have to recognize same-sex marriages. ${ }^{150}$ The decision stirred such virulent political opposition that fifteen states passed ballot initiatives the next election cycle limiting marriage to heterosexual couples and Congress passed the Defense of Marriage Act enabling states to ignore same-sex marriages from other states. ${ }^{151}$

In addition to provoking backlash among conservatives, Baehr is often credited with triggering widespread changes in mainstream LGBT activism. Previous empirical work suggests that Baehr motivated the major gay and lesbian civil rights groups to begin prioritizing same-sex marriage. ${ }^{152}$ The initial Baehr decision in 1993 motivated one of the largest national LGBT rights organizations, Lambda Legal, to intervene as co-counsel for appeals in the case. ${ }^{153}$ Lambda later established a Marriage Project that aimed to "coordinate and facilitate state-by-state political organizing and public education around the issue of same-sex marriage." 154 Since then, all of the major

${ }^{146}$ Baehr, 852 P.2d at 60-63.

${ }^{147}$ CAIN, supra note 48, at 259 (discussing how the Hawaii litigation "became the focus of the entire nation.").

${ }^{148}$ See Kevin Williams, Dying of Ignorance? Journalists, News Sources and the Media Reporting of HIV/AIDS, in Social Policy, the Media and Misrepresentation 69, 69 (Bob Franklin ed., 2d ed. 2002).

${ }^{149}$ Gerald N. Rosenberg, The Hollow Hope: Can Courts Bring About Social Change? 362 (2d ed. 2008).

${ }^{150}$ See id.

${ }^{151}$ Michael C. Dorf \& Sidney Tarrow, Strange Bedfellows: How an Anticipatory Countermovement Brought Same-Sex Marriage into the Public Arena, 39 Law \& Soc. INQUIRY 449, 455 (2014).

${ }^{152}$ ANDERSEN, supra note 88, at 177-78 ("[U]ntil 1993, none of the major gay legal groups treated same-sex marriage as an immediate priority. That all changed when the Hawaii Supreme Court handed down its groundbreaking decision in Baehr v. Lewin.").

${ }^{153}$ Id. at 179 ("The 1993 decision in Baehr . . . served as the impetus for widespread gay rights mobilization around same-sex marriage rights. Preeminent among the newly mobilized in this area was Lambda. After the decision came down, Lambda reversed its earlier stance of nonaction with respect to same-sex marriage. Part of the reason for this reversal may have been staff turnover . . . Interviews with present and former staff members, though, indicate that the legal opening provided by Baehr was the primary stimulus for Lambda's change of heart.").

${ }^{154} \mathrm{Id}$. 
LGBT legal groups have taken cases and created projects devoted to samesex marriage. ${ }^{155}$ This legal mobilization led to a series of highly visible successes throughout the 2000s, with state high courts in Massachusetts, ${ }^{156}$ California, ${ }^{157}$ Connecticut, ${ }^{158}$ and Iowa ${ }^{159}$ finding the right of same-sex couples to marry in their states' constitutions. LGBT rights groups initially sought to avoid the federal courts, which they perceived as a hostile and risky venue for marriage equality claims. ${ }^{160}$ However, private attorneys opened the floodgates to the federal courts in 2012 with the U.S. Supreme Court cases Hollingsworth v. Perry ${ }^{161}$ and United States v. Windsor. ${ }^{162}$ Although these decisions did not directly rule on the validity of same-sex marriage bans, the Court's sweeping language provided significant traction for arguments that such bans violated the U.S. Constitution. ${ }^{163}$ After those decisions, LGBT movement organizations and private attorneys alike have brought dozens of cases challenging marriage bans in both state and federal court. ${ }^{164}$

This section has traced the development of same-sex marriage from its original position as a radical, fringe issue to its current position at the heart of LGBT activism. Expanding on recent work, ${ }^{165}$ this account further problematizes the standard historical account of same-sex marriage activism, which draws a bright line between "assimilationist" marriage advocacy efforts and "radical" queer and liberationist politics. Instead, our analysis supports the emerging view of marriage equality as a political issue that can

${ }^{155} I d$. at $184-85$ (describing how "[m] uch had changed" in discussions among the major gay rights litigation organizations within six years of Baehr: "The major groups all agreed that the time was right to push the legal envelope still further" on same-sex marriage).

${ }^{156}$ Goodridge v. Dep't. of Pub. Health, 798 N.E.2d 941 (Mass. 2003).

${ }^{157}$ In re Marriage Cases, 183 P.3d 384 (Cal. 2008).

${ }^{158}$ Kerrigan v. Comm'r of Pub. Health, 957 A.2d 407 (Conn. 2008).

${ }^{159}$ Varnum v. Brien, 763 N.W.2d 862 (Iowa 2009).

${ }^{160}$ See ANDERSEN, supra note 88, at 227.

161133 S. Ct. 2652, 2668 (2013).

162133 S. Ct. 2675, 2696 (2013). In addition to private attorneys, the Windsor case was led by co-counsel at the American Civil Liberties Union and New York Civil Liberties Union. Complaint, Windsor v. United States, 833 F. Supp. $2 d 394$ (S.D.N.Y. 2012) (No. 10-CV-8435).

${ }^{163}$ See Windsor, 133 S. Ct. at 2694 ("DOMA's principal effect is to identify a subset of state-sanctioned marriages and make them unequal. The principal purpose is to impose inequality, not for other reasons like governmental efficiency. Responsibilities, as well as rights, enhance the dignity and integrity of the person. And DOMA contrives to deprive some couples married under the laws of their State, but not other couples, of both rights and responsibilities .... This places same-sex couples in an unstable position of being in a second-tier marriage. The differentiation demeans the couple, whose moral and sexual choices the Constitution protects.")

${ }^{164}$ See Marriage Litigation, FreEdom to MARRY, http://www.freedomtomarry.org/ litigation, archived at http://perma.cc/N5PW-6YEP.

${ }^{165}$ See Boucai, supra note 38; NeJaime, Before Marriage, supra note 82. 
assume new and quite different meanings depending on the historical and cultural context in which it is advocated.

This historical account of the shifting meaning and politics of same-sex marriage illustrates several points that are relevant to poly marriage activism today. First, it shows that mobilization around state relationship recognition can take various forms - each of which offers a distinct model of legal mobilization that poly activists may choose to implement. One form of marriage mobilization sees demanding marriage equality as a radical form of politics. Like many poly activists today, lesbian and gay activists have historically been mindful of the problematic nature of marriage as a patriarchal institution that involves the state in privileging certain forms of intimacy over others. ${ }^{166}$ Yet as this Part shows, it is possible for activists to construct alternative, radical models of marriage litigation if they are so inspired. PreBaehr marriage equality activists, facing certain defeat in court, pursued marriage litigation in part to expose and protest the injustice marriage produces - a radical message aimed to destabilize marriage as an institution. By contrast, the more recent models of gay and lesbian litigation-the nonmarital relationship recognition campaign and the post-Baehr campaign for marriage equality-exemplify the more careful, incremental approach that impact litigation groups are known for taking.

Second, this Part has given several examples of how the legal and cultural climate in which a movement operates (along with the shared norms among activists within a given movement) can fundamentally shape the types of strategies those actors will pursue. In the gay liberation years, the lack of legal or cultural resonance around same-sex marriage created the possibility for a marriage equality campaign that promoted transgression and furthered radical ideals. Once the legal doctrine and cultural ideas about homosexuality had shifted enough that marriage rights were actually within LGB people's reach, the meaning of demanding marriage became equivalent to the desire to access a prominent social institution-not to destroy it. ${ }^{167}$ Thus, the increasing legal acceptance and cultural acclimatization toward same-sex relationships reconstituted the meaning of marriage equality litigation, such that the more assimilationist LGBT movement groups that eventually became the movement's mainstream organizations could come to accept the strategy as a central one on their agenda.

166 The Loving More survey revealed ambivalence about marriage among a majority of respondents. See What Do Polys Want?, supra note 30 (reporting that $66.9 \%$ of respondents thought that no relationship structure "deserve[d] special recognition"). See also infra Part I (discussing similar ambivalence in the pre-1993 LGBT movement).

${ }^{167}$ For this reason, the pursuit of marriage rights in the abstract cannot be considered an inherently assimilationist or radical goal. 


\section{The Polyamorous Community and Its (Multiple) VieWs ON MARRIAGE}

The radical roots of LGBT marriage activism, and the comparison to the radical notion of multiparty marriage today, may suggest that the polyamorous community currently occupies the same political, cultural, and legal space that gay liberationists occupied in the 1970s. However, that would be a simplistic, ahistorical notion that ignores the fact that poly activism today operates in spaces and against constraints formed, in part, by the struggles, successes, and failures of the LGBT community, and therefore in a more nuanced and complicated legal, political, and cultural terrain than that which surrounded gay liberationists in the early days of "marry-ins" and radical protest. In order to understand the complex relationships between the two movements, we proceed to provide background on the polyamorous community, its activists and advocates, and the way in which members of the community relate to the marriage equality struggle.

\section{A. Polyamory: Definition, Nomenclature, Demographics}

Polyamory, a portmanteau of Greek and Roman words, ${ }^{168}$ is a term coined in 1990 by Morning Glory Zell-Ravenheart, a well-known public figure in the Pagan and polyamorous communities, to describe "the custom or practice of engaging in multiple sexual [or, for some, romantic] relationships with the knowledge and consent of all partners concerned." 169 Before the 1990s, it was common to refer to similar lifestyles and practices as "re-

${ }^{168}$ Interestingly, "homosexuality" is also a blend of Greek and Roman words, causing some disfavor for the term in its early adoption. Siobhan Somerville, Scientific Racism and the Invention of the Homosexual Body, in Queer Studies: A Lesbian, Gay, Bisexual \& Transgender Anthology 241, 249-50 (Brett Beemyn \& Mickey Eliason eds., 1996).

${ }^{169}$ Robyn Trask \& Alan M., What is Polyamory?, Loving More, http://www.love more.com/home/what-is-polyamory/, archived at http://perma.cc/55HN-2MSZ; see also Maura I. Strassberg, The Challenge of Post-Modern Polygamy: Considering Polyamory, 31 Cap. U. L. Rev. 439, 439-40 (2003). For some relationship activists who are "polyfriendly," however, an important aspect of polyamory is its contribution to the appreciation of nonsexual love as equally important and meaningful. See Wendy-O MAtiK, Redefining Our Relationships: Guidelines for Responsible Open Relationships (2002) (discussing nonsexual, as well as sexual, concept of multiple loves: "An open relationship cannot be reduced to the act of sex alone. There are more than a thousand ways to make love, to recreate intimacy in your every day life, to suck the juices from a piece of fruit and feel full for the first time. Being in an open relationship means you have the revolutionary opportunity to have guilt-free sex with life, with yourself, with your soul. Expand your notions of eroticism, rediscover verbal and written affection, invent a new way to hug that truly expresses how much you feel for that person, massage every inch of your lover's body without making sex the goal."); Valerie White, Polyamory and the Law, Loving More, Winter 2002, at 7, 7-10 (discussing legal consequences of polyamory). 
sponsible nonmonogamy." 170 Many polyamorous people stress the distinction between polyamory and swinging, ${ }^{171}$ which some define as involving sexual exchanges between couples rather than full relationships of more versatile patterns. ${ }^{172}$ It is frequently argued that polyamory is the opposite of "cheating"; ${ }^{173}$ whereas cheating is defined by frequent ${ }^{174}$ and discreet sexual infidelities in ostensibly monogamous couples, the practice of polyamory is built on a foundation of honesty and consent.

There are various types and structures of polyamorous relationships, ${ }^{175}$ and the community members' fierce individualism often stands in the way of providing one way of "how to do polyamory right." 176 Many polyamorous relationships consist of a "primary" dyad, a couple sharing a household, in which each partner also has "secondary" and "tertiary" relationships with outsiders to the household. ${ }^{177}$ "While this arrangement is fairly common, ${ }^{178}$ and the "primary/secondary" terminology is in wide use, ${ }^{179}$ many polyamorous people tend to regard the structure as overly confining, arguing instead that all their relationships, though different in nature, involve love and commitment. ${ }^{180}$ Other common structures are the "polyamorous vee," in which two people have romantic relationships with the same person, but not

170 See Deborah M. Anapol, Polyamory: The New Love Without Limits: Secrets of Sustainable Intimate Relationships 5 (1997) [hereinafter Anapol, Polyamory: The New Love Without Limits] ("The term polyamory was first proposed by Church of All Worlds founders Oberon and Morning Glory Zell to replace the awkward expression responsible nonmonogamy."); Marcia Munson \& Judith P. Stelboum, Introduction to The Lesbian Polyamory Reader: Open Relationships, Non-Monogamy, And Casual Sex 1, 1 (Marcia Munson \& Judith P. Stelboum eds., 1999) ("In the 1980s, the term 'non-monogamy' was used to describe multiple concurrent sexual involvements.").

${ }^{171}$ Serolynne, Compare and Contrast: Polyamory vs. Swinging, Serolynne, http:// www.serolynne.com/polyvsswing.htm, archived at http://perma.cc/LZ6C-7VAX.

${ }^{172}$ Christina Richards \& Meg Barke, Sexuality and Gender for Mental Health Professionals: A Practical Guide 209 (2013).

${ }^{173}$ For an explanation of the honesty, disclosure, and communication paradigm beyond poly relationships, listen to Beyond Monogamy (KQED radio broadcast Feb. 13, 2015), http://www.kqed.org/a/forum/R201502131000, archived at http://perma.cc/L2CX9ZPS.

${ }^{174}$ Multiple studies of heterosexual fidelity have found that around one-third of men and one-quarter of women report at least one instance of sexual infidelity during a monogamous relationship. See Kristen P. Mark, Erick Janssen \& Robin R. Milhausen, Infidelity in Heterosexual Couples: Demographic, Interpersonal, and Personality-Related Predictors of Extradyadic Sex, 40 Archive Sexual Behav. 971, 971 (2011).

175 Anapol, Polyamory: The New Love Without Limits, supra note 170, at 9.

${ }^{176}$ Aviram, Make Love, Not Law, supra note 26, at 281 (discussing a common sense among polyamorous respondents that it was inappropriate to enforce a "correct" way of living in polyamorous relationships).

177 See Anapol, Polyamory: The New Love Without Limits, supra note 170, at 9; RichARDS \& BARKE, supra note 172, at 209-10.

${ }^{178}$ Aviram, Make Love, Not Law, supra note 26, at 269.

179 See Tristan Taormino, Opening Up: A Guide to Creating and Sustaining Open Relationships 74-77 (2008) (explaining the usefulness of hierarchical poly models for some relationships).

${ }^{180}$ See Serena Anderlini-D’Onofrio, Polyamory, in Sexuality: The Essential GlosSARY 164, 164-65 (Jo Eadie ed., 2004). 
with each other (though they may share a nonromantic sense of affection and commitment); a triad or a quad, in which all three or four members are romantically involved with each other; or an intimate network of friends, in which relationships are more fluid and involve several people in different and ever-changing relationship structures. ${ }^{181}$ All these structures may, or may not, involve "polyfidelity" - a commitment to have sexual or romantic relationships only with members of the group. ${ }^{182}$ Growing concerns about sexually-transmitted diseases have popularized careful protocols, such as adherence to clear disclosures regarding number of partners and a general attitude of caution regarding "fluid bonding" (sexual intercourse without barrier methods). ${ }^{183}$

The versatility in genders, sexual orientations, and sexual identities distinguishes the polyamorous community from other groups that practice nonmonogamy as part of a religious or ethnic tradition, and activists frequently identify the differences. ${ }^{184}$ The Loving More survey revealed a high percentage of people involved in relationships with partners of both sexes ( $46.3 \%$ for women, $18.8 \%$ for men). ${ }^{185}$ The high percentage of same-sex relationships in the poly community suggests that there may be some amount of overlap in poly and LGBT communities and may help explain why many poly activists have expressed support for the LGBT movement's marriage equality campaign. ${ }^{186}$

${ }^{181}$ See Anapol, Polyamory: The New Love Without Limits, supra note 170, at 7-9; Robert McGarey, Poly Communication Survival Kit: The Essential Tools FOR BuIlding AND ENhancing Relationships 5 (1999).

182 See Anapol, Polyamory: The New Love Without Limits, supra note 170, at 9. Polyfidelity was more common in the early days of the movement, such as in the Kerista collective. See Ayala Pines \& Elliot Aronson, Polyfidelity: An Alternative Lifestyle without Jealousy?, 4 Alternative LifEstyles 373, 373-74 (1981).

${ }^{183}$ See Richards \& BARKe, supra note 172, at 210-11. For a critique of "fluid bonding" as a strategy for preventing sexually-transmitted diseases, see Jenny Ford, What They Don't Tell You about STDs and Non-Monogamy, The Polyamorous Misanthrope (2007), http://www.polyamorousmisanthrope.com/2007/07/29/what-they-dont-tell-youabout-stds-and-non-monogamy/, archived at http://perma.cc/RHQ2-HZ2D (arguing that the need to confirm the health status of multiple partners can be unsustainable even when some of the participants are "fluid-bonded" and some are not).

${ }^{184}$ See Aviram, Make Love, Not Law, supra note 26, at 274.

${ }^{185}$ What Do Polys Want?, supra note 30.

${ }^{186}$ See infra Part II.C (discussing perceptions of the marriage equality struggle among polyamorous people). In addition, the polyamorous population was significantly more educated than the general U.S. population: $35 \%$ of respondents had a bachelor's degree and $27.4 \%$ had a graduate degree, compared with $17.9 \%$ and $10.4 \%$ respectively in the general population. What Do Polys Want?, supra note 30. Household composition also varied, but included, on average, more adults and fewer children than in the general population. $I d$. The survey also found polyamorous respondents to be happier, in better health, and experiencing more sex with more partners than the general population. $I d$. 


\section{B. A Brief History of the Polyamorous Community}

The practice of the set of lifestyles referred to since 1990 as "polyamory" can be traced to the 1960s movements of free love and sexual freedom. ${ }^{187}$ It was during this era that nonmonogamy became much more culturally prevalent, with the popularization of swinging (a practice closely associated with polyamory until the 1980s) $)^{188}$ and the diffusion of sexual liberation organizations, communes, and magazines. ${ }^{189}$ While in the early 1960s there were hardly any cultural role models or resources for people seeking nonmonogamy, the mid-1960s offered more such resources, such as Jefferson Airplane's song Triad ${ }^{190}$ and Robert Heinlein's influential science fiction novel Stranger in a Strange Land. ${ }^{191}$ Heinlein's book, which is still regarded by many poly activists as the catalyst for their lifestyles, ${ }^{192}$ tells the story of a man raised on Mars who returns to Earth and teaches a group of humans about Martian culture, including a life in "nests"-intimate network units of men and women who reside together and share love in a non-possessive fashion. ${ }^{193}$ The book found a particularly enthusiastic readership among members of the Pagan community, which, inspired by its plot, founded a real-life spiritual organization, the Church of All Worlds (CAW) that provided the framework for a life in familial "nests," as well as published an alternative magazine, Green Egg, which ran from 1968 to 2001. ${ }^{194}$ At the time, other communes - not necessarily affiliated with Paganism or Earthbased spirituality - came into existence. The Kerista collective, which existed in the 1970s in San Francisco, ran a successful computer dealership, and was composed of families with thirty-six members each. ${ }^{195}$ The collective relied on a model of polyfidelity (fidelity within each family) and on a rotational sleeping schedule between its members. ${ }^{196}$

${ }^{187}$ See Maura Irene Strassberg, Distinguishing Polygamy and Polyamory Under the Criminal Law, in Families-Beyond the Nuclear Ideal 160, 166 (Daniela Cutas \& Sarah Chan eds., 2012).

${ }^{188}$ See Pepper Mint, "Border Wars: Swinging and Polyamory" at Building Bridges IV, (Oct. 16, 2004) (unpublished paper), http://pepperminty.com/writing/swingingand polyamory.pdf, archived at http://perma.cc/NCZ7-49X3.

${ }^{189}$ Panel, Margo Rila, Maggi Rubenstein \& Jerry Zientara, Scenes from the Late 60's Sexual Culture in the Bay Area, Society for the Scientific Study of Sexuality Annual Meeting: Unstudied, Understudied and Underserved Sexual Communities (May 6, 2005) (conference program on file with first author).

${ }^{190}$ JefFerson Airplane, TRiad (RCA Victor 1968).

${ }^{191}$ Robert A. Heinlein, Stranger in a Strange Land (1961).

192 Deborah Anapol, Polyamory in the Twenty-First Century: Love and Intimacy with Multiple Partners 50-51 (2010).

${ }^{193}$ Heinlein, supra note 191. See also Lewis Call, BDSM in American Science Fiction AND FANTASY 20 (2012).

${ }^{194}$ See About Green Egg, Green EgG: Legendary Journal of the Awakening EARTH, http://www.greeneggzine.com/about_green_egg_23.html, archived at http://per ma.cc/56LT-BS92.

${ }^{195}$ Suzann Robins, Remembering the Kiss . . . , 4 J. BiseXuality 99, 102 (2004).

${ }^{196}$ Anapol, Polyamory in the Twenty-First Century, supra note 192, at 57. 
While some polyamorous relationships adhere to a polyfidelity model like that used in the Kerista collective, there is a deep resistance within the polyamorous community to such compulsory limitations on sexual partnering outside of established relationships. ${ }^{197}$ Indeed, such regulations on partnering are a key component of monogamy, the sexually regulatory institution that polyamorists collectively resist. ${ }^{198}$ This resistance to monogamy-the core value that unites the individuals in quite diverse polyamorous relationship structures-resonates strongly with not only a sexual-liberationist philosophy, but also with feminist and queer political philosophies. The feminist critique of monogamy highlights how norms against infidelity are more binding on women than men and are historically rooted in a proprietary view of women. ${ }^{199}$ Several polyamorous commentators cite such feminist understandings of monogamy and women's sexual control as a driving force in their decisions to pursue polyamory, ${ }^{200}$ creating a visible sex-positive feminist presence in the polyamorous community. ${ }^{201}$

In addition to feminism, queer politics has also deeply influenced polyamory. As noted above, queer politics emerged in the 1980s as a fiery new brand of confrontational sexuality-based activism. ${ }^{202}$ Queer politics emerged in response to both the virulent stigmatization of deviant sexualities in the wake of the AIDS epidemic and the increasingly rigid use of identity politics by mainstream lesbian and gay rights organizations. ${ }^{203}$ The queer approach was concertedly more inclusive than traditional lesbian and gay politics, and focused on cultivating pride in multiple stigmatized sexual practices in addition to homosexuality (e.g., BDSM and nonmonogamy). ${ }^{204}$ The openness of

${ }^{197}$ See Emens, supra note 25, at 325 ("A number of prominent poly writers describe their embrace of polyamory as fueled by their insights about power and possessiveness in monogamy and by their desire for autonomy within their relationships.”).

${ }^{198} I d$.

${ }^{199}$ See Judith P. Stelboum, Patriarchal Monogamy, in The Lesbian Polyamory READER, supra note 170, at 39, 42 ("Feminist scholars state that the origins of monogamy have their source in patriarchal thinking. Viewed as the possessions of the male, women were used for barter and/or procreation. . . . Legitimacy of a child relates to acknowledgement of the child's father, not to the child's mother.").

${ }^{200}$ Emens, supra note 25, at 325 ("[Prominent poly writers' embrace] of polyamory builds in part on the feminist understanding of monogamy as a historical mechanism for the control of women's reproductive and other labor.").

${ }^{201}$ These sexual liberationist and feminist aspects of polyamory distinguish it from the religiously founded multiparty relationships such as polygyny. See id. at 307 ("[T]he sex-based hierarchy of traditional Mormon polygyny seems incompatible with the typical poly dedication to principles of equality and individual growth, causing some polys and commentators to exclude Mormon polygyny from the umbrella of polyamory."); Joan Iversen, Feminist Implications of Mormon Polygyny, 10 Feminist Stud. 505, 518 (1984) ("One cannot truly apply the term 'feminist' to the Mormon plural wives because feminism and patriarchal religion are incompatible.").

${ }^{202}$ See supra Part I.B.

${ }^{203}$ See Steven Seidman, Symposium: Queer Theory/Sociology: A Dialogue, 12 Soc. THEORY 166, 172 (1994).

${ }^{204}$ Michael Warner, The Trouble with Normal: Sex, Politics, and the Ethics OF QUEER LiFE 66 (1999) (arguing that queer life is about rejecting normativity and includes " $\mathrm{t}] \mathrm{he}$ others, the queers who have sex in public toilets, who don't 'come out' as 
queer politics to sexual diversity, and the common stigmatization of nonmonogamy and homosexuality provoked by AIDS-phobia, created a natural affinity between polyamorous and queer communities. ${ }^{205}$ In certain places, such as San Diego, polyamorous activism became closely linked to queer, and specifically bisexual, activism; for bisexual polyamorists, nonmonogamy was the path for manifesting their sexual orientation, in that it allowed them to conduct relationships with people of both genders simultaneously. ${ }^{206}$

Another important force in the development of the polyamorous community was the advent of the internet and its function as a social resource. Polyamorous activists interviewed by the first author in 2005 were technologically sophisticated, and various technological vocations were overrepresented in the interview sample. ${ }^{207}$ Currently, there is a wide variety of internet resources available for polyamorous people who need advice and help ${ }^{208}$ as well as a specialized dating website. ${ }^{209}$ The mainstream dating website OKCupid caters to non-monogamous clients. ${ }^{210}$ There are also webbased "meet-up" groups for the purpose of meeting new potential partners, as well as befriending other poly people and exchanging advice and support. ${ }^{211}$

Offline polyamorous community support systems range from the national organization, Loving More, which publishes the magazine and runs two regional conferences per year, to local groups that meet on a regular basis for social purposes. Most of the first author's interviewees attended Loving More weekend workshops and/or workshops run by the Human Awareness Institute. ${ }^{212}$ The workshops focus mostly on the emotional management of polyamorous relationships, and are designed to help attendees develop skills such as jealousy management, conflict resolution, and the development of "compersion"-vicarious joy and empathy for a loved one who is involved with someone else. ${ }^{213}$ Online lists such as SfBay-Poly in the

happily gay, the sex workers, the lesbians who are too vocal about a taste for dildos or S/ $\mathrm{M}$, the boys who flaunt it as pansies or as leathermen" and other sexual minorities).

${ }^{205}$ This is especially true for bisexual men. The fear of AIDS increased the visibility of bisexual men, who were blamed for spreading the disease to the straight population. Interview with Claire, activist (2005) (transcript on file with first author).

${ }^{206} I d$.

${ }^{207}$ Aviram, Make Love, Not Law, supra note 26, at 267.

${ }^{208}$ See, e.g., Love Outside THE Box, http://www.loveoutsidethebox.com, archived at http://perma.cc/2UA6- BGMK (providing workshops on polyamorous relationships).

${ }^{209}$ See PolymatchmaKeR, http://www.polymatchmaker.com, archived at http://per ma.cc/R39F-9LG4.

${ }^{210}$ See OKCUPID, https://www.okcupid.com, archived at https://perma.cc/573XPH MB. See also Matt Albrecht, Poly Culture and Online Dating, Model VIEw Culture (Sept. 8, 2014), https://modelviewculture.com/pieces/poly-culture-and-online-dating, archived at https://perma.cc/93F5-W69N.

${ }^{211}$ POLYAMORY MeETUPS, http://polyamory.meetup.com, archived at http://perma.cc/ J96P-33J2.

${ }^{212}$ See HAI Global, http://www.hai.org, archived at http://perma.cc/7S66-3PCL.

${ }^{213}$ Emens, supra note 25, at 330. 
San Francisco Bay Area host events on a regular basis, both socially and to discuss articles and courses of action. ${ }^{214}$ In addition, various subcultures of the Bay Area, though not polyamorous by definition, are particularly friendly to polyamorous individuals; some of these communities include science fiction conventions, Pagan and queer forums, the Society for Creative Anachronism and other historical-recreational venues, and several left-wing, progressive social milieus. ${ }^{215}$

\section{Polyamorous Perspectives on the Same-Sex Marriage Struggle}

There have been, overall, two efforts to gauge the perception of the marriage equality struggle among polyamorous people. The first was a series of in-depth interviews conducted by the first author in 2005 with "active and salient" members of the polyamorous community in the San Francisco Bay Area. ${ }^{216}$ The second was the aforementioned large-scale web survey conducted by Loving More and NCSF in 2012.217 While the different methodologies and populations do not allow for a direct quantitative comparison, the time difference between the two seems to suggest an increase in community enthusiasm about the prospect of legal recognition, likely prompted by the success of the struggle for same-sex marriage.

Polyamorous people, of course, are well aware of the fact that they cannot be legally married to more than one partner. Since 1862 (and later amended in 1882 and 1887), federal law has prohibited polygamy, ${ }^{218}$ and there have been no attempts, outside the context of Mormon polygamy, ${ }^{219}$ to revise the legal status of multiple marriages. Until the mid-2000s, the only publicized attempt to obtain legal recognition for a polyamorous relationship involved a child custody battle in Tennessee, between a polyamorous mother, April Divilbiss, and the paternal grandmother, which ended in the mother's loss of custody. ${ }^{220}$ Most of the first author's interviewees in 2005 were familiar with the Divilbiss case and mentioned it as a cautionary tale regarding mobilization for legal rights. 221

${ }^{214}$ See SFBAY-POLY, http://lists.polyamory.org/listinfo.cgi/sfbay-poly-polyamory.org, archived at http://perma.cc/6QBS-SP9Q.

${ }^{215}$ Aviram, Make Love, Not Law, supra note 26, at 266-67, 276-77.

${ }^{216} I d$. at 266.

${ }^{217}$ What Do Polys Want?, supra note 30.

${ }^{218}$ Act of July 1, 1862 ("Morrill Anti-Bigamy Act"), 12 Stat. 501, repealed by Act of Nov. 2, 1978 § 2, Pub. L. No 95-584, 92 Stat. 2483, 2483.

${ }^{219}$ While traces of the practice of polygamy remained among the Mormon community, see Reynolds v. United States, 98 U.S. 145, 164 (1878), the Church of Latter-Day Saints only renounced the practice in 1890. See Elizabeth Harmer-Dionne, Once a Peculiar People: Cognitive Dissonance and the Suppression of Mormon Polygamy As a Case Study Negating the Belief-Action Distinction, 50 Stan. L. Rev. 1295, 1300 (1998).

${ }^{220}$ Emens, supra note 25, at 309-12.

${ }^{221}$ Aviram, Make Love, Not Law, supra note 26, at 278; see also first author's field notes (on file with first author). 
The interviewee group was, overall, very political and active, and there was a surprising juxtaposition between their vibrant involvement in workshops, conferences, meet-ups, potlucks, and other poly-themed events and their overall lack of enthusiasm for legal mobilization. ${ }^{222}$ Many of the first author's interviewees were dyadic primary couples with lovers outside the household, who had no desire to legally formalize their relationships with their secondary partner. The members of "vees," triads, and quads in the study, particularly those who had spent several years as a family unit, used various contractual mechanisms, such as wills, trusts, power-of-attorney documents, and the like, to mimic some of the economic and logistical aspects of marriage and facilitate management of the household.223 These mechanisms strongly resembled those advocated by attorneys for cohabitating, unmarried same-sex and opposite-sex couples. ${ }^{224}$

Beyond the lack of a strong "push" for instrumental rights and benefits, the first author's interviewees reported political and cultural reasons for their reluctance to mobilize legally. Many interviewees expressed disdain of identity politics ${ }^{225}$ and a strong sense of individualism and personal agency, which made them resent governmental interference with their personal and emotional life. ${ }^{226}$ The interviewees repeatedly stressed the importance of freedom and fluidity in personal relationships, which, for them, meant that seeking the mainstream's stamp of approval in the form of yet one more oppressive "box" to check on official forms would be an unwanted concession. ${ }^{227}$

The first author attributed this strong support of self-actualization and visionary individualism in part to the cultural locus of the community she studied, which had roots in visionary science fiction and fantasy literature as well as in earth-centered religions, ${ }^{228}$ but also to the extent to which respondents identified with queer politics and ideology. ${ }^{229}$ Many of the first author's interviewees identified as bisexual or refused to identify as having any particular sexual orientation. ${ }^{230}$ Moreover, several interviewees mentioned the overlap between polyamorous lifestyles, the BDSM and kink community,

${ }^{222}$ Aviram, Make Love, Not Law, supra note 26, at 279.

${ }^{223} \mathrm{Id}$. at 269-70 (referencing wills and power-of-attorney documents).

${ }^{224}$ See, e.g., Kate Kendell, Gain Legal Protection for Gay Families, in 50 WAYs to SupPort Lesbian \& GAy EQuality 86, 87-88 (Meredith Maran \& Angela Watrous eds., 2005) ("If you're a same-sex couple living in a state without domestic partner recognition, make sure you have a will or trust, powers of attorney for health care and finances, a nomination of guardianship ... a and a co-parenting agreement.").

${ }^{225}$ Aviram, Make Love, Not Law, supra note 26, at 271-72.

${ }^{226}$ Id. at 278.

${ }^{227}$ Id. at 279.

${ }^{228}$ Hadar Aviram, Geeks, Goddesses, and Green Eggs: Political Mobilization and the Cultural Locus of the Polyamorous Community in the San Francisco Bay Area, in UNDerstanding Non-Monogamies 87, 89-90 (Meg Barker \& Darren Langdridge eds., 2010).

${ }^{229}$ Aviram, Make Love, Not Law, supra note 26, at 267.

${ }^{230} \mathrm{Id}$. 
and other sex-positive communities. ${ }^{231}$ As sexual minorities in more than one way, the interviewees were concerned about the need to go "vanilla" and present a socially palatable, sex-negative image to the public in the effort to attain legal recognition. ${ }^{232}$ The interviewees' identification with sexual minorities was also important to them in that they understood the same-sex marriage struggle as incremental. ${ }^{233}$ Several interviewees mentioned that same-sex marriage must take precedence over any effort on behalf of polyamorous families, saying that their "gay and lesbian brothers and sisters" deserve "their moment in the sun," and that it would be timelier for public opinion to mature into acceptance of multipartner relationships after samesex marriage became acceptable. ${ }^{234}$

The 2012 Loving More and NCSF survey suggests that the passage of time since the first author's study, and the success of same-sex marriage legalization efforts, may have produced more favorable approaches toward legalization among community members. When presented with the question, "if it were legal, would you be open to being legally married to more than one person concurring," $76.7 \%$ of respondents answered "yes." 235 Moreover, a large majority-91.9\% of all respondents and $93.1 \%$ of currently unmarried respondents-agreed or strongly agreed with the statement, "consensual, multiparty marriages among adults should enjoy the same legal recognition, privileges and obligations as two-party marriages." ${ }^{.36}$ However, this seemingly strong support hides a more nuanced and complex understanding of the law's place in intimate relationships. A reported $66.9 \%$ of all respondents, and $70.6 \%$ of unmarried respondents, believed that no relationship configuration deserved special recognition or privileges over others, but the problematic phrasing of the question does not allow us to conclude whether the privileged "relationship configuration" in the question was monogamous marriage, multiparty marriage, or any other formalized family arrangement. ${ }^{237}$ At best, we can conclude that the interest in, and enthusiasm for, legal recognition for multiparty relationships is complicated by a resentment over prioritization of legally recognized relationships for various legal aspects. This interpretation is supported by comments from the first author's interviewees, who stated, for example, that rather than advocating for health

${ }^{231} I d$. at 273.

${ }^{232} \mathrm{Id}$. at 271.

${ }^{233} \mathrm{Id}$. at 274.

${ }^{234} I d$.

${ }^{235}$ What Do Polys Want?, supra note 30.

${ }^{236} \mathrm{Id}$.

${ }^{237}$ Id. The exact phrasing of the question was: "Jones believes that any form of intimate relationship between consenting adults is fine, but that none deserve special recognition or privileges. Smith believes that certain types of relationships are more socially valuable than others and deserve official recognition and privileges in order to encourage their formation." Id. Respondents were asked whether they agreed with Jones or with Smith. Id. 
care via multipartner marriage, they would prefer to see universal health care offered to all U.S. residents, regardless of their familial status. ${ }^{238}$

The renewed interest in legal mobilization and political action is manifested beyond survey answers. Two well-attended community conferences, the World Polyamory Association's meeting in the summer of $2013^{239}$ and the annual International Academic Conference on the Future of Monogamy and Nonmonogamy, ${ }^{240}$ featured a "political summit" in which various alternative approaches to legal recognition were discussed. ${ }^{241}$ Activists' exploration of the pros and cons of legal mobilization were notably informed by the same-sex marriage struggle, and the suggestions made at the summits often echoed strategies actually employed in the same-sex marriage context, such as arriving innocently to City Hall and requesting a marriage license for three people. ${ }^{242}$

In summary, as this background to the two communities suggests, while the polyamorous community is far from identical in composition to the gay liberationists of the 1970s, there are some pertinent similarities that inform the analysis of legal strategies. Gay liberationist and polyamorous communities have expressed similar normative commitments to inclusivity and sexual diversity, as well as a drive for individual autonomy that resists a centralized or uniform approach to politics. ${ }^{243}$ Members of these communities also generally ascribe to progressive political values, rooted in feminist and sexual liberationist ideals. ${ }^{244}$ This may explain the ambivalence voiced by members of both communities around the idea of pursuing marriage rights; while drawn to marriage, gay liberationists and polyamorists have remained mindful of the problematic nature of marriage as a patriarchal institution that involves state privileging of certain forms of intimacy over others. ${ }^{245}$

In addition to these internal similarities, the contemporary polyamorous community confronts a similar cultural environment to the one confronted by the gay liberationists of the 1970s. In both communities, conservative backlash began mounting even before marriage equality efforts were officially underway; just as conservative rhetoric around the ERA once prompted preemptive opposition to same-sex marriage, ${ }^{246}$ conservative rhet-

${ }^{238}$ First author's field notes (on file with first author). Kathy, the interviewee, went on to discuss how compliance with "check the box" forms regarding relationship status indicated compliance with marriage-based policies, specifically healthcare policies, which she was not willing to support. Id.

${ }^{239}$ See 2013 Conference, World Polyamory Association, http://worldpolyamory association.net/conferences/2012-poly-con/\#.VN5zyfnF-UY, archived at http://perma.cc/ 2F26-8QYN.

${ }^{240}$ See Monogamy and Nonmonogamy 2015, https://sites.google.com/site/monogamy andnonmonogamy2015/, archived at https://perma.cc/H6B7-45CW.

${ }^{241}$ First author's field notes (on file with first author).

${ }^{242} I d$.

${ }^{243}$ See supra Parts I.A and II.B.

${ }^{244}$ See supra Parts I.A and II.B.

${ }^{245}$ See supra Parts I.A and II.C.

${ }^{246}$ See supra Part I.A. 
oric around same-sex marriage has recently prompted preemptive opposition to polyamorous marriage. ${ }^{247}$ Also like the gay liberationists before them, polyamorists have been abandoned by perceived allies in the wake of this backlash: feminist advocates of the ERA refused to respond to gay baiting with a defense of same-sex marriage, ${ }^{248}$ a striking parallel to the recent LGBT advocates' response to the "slippery slope" arguments against samesex marriage. ${ }^{249}$ Thus, while one might assume that the LGBT movement's continuous work toward marriage equality since the 1990s would have created a cultural opening to alternative marriage structures, winning the legal battle for polyamorous marriage is just as unthinkable today as winning the battle for same-sex marriage was during the era of gay liberation.

More generally, LGBT and polyamorous communities are similarly institutionally situated in a way likely to generate common strategic innovations and raise common challenges. These groups' subordination arises largely from the social institutions that define and regulate sexuality. ${ }^{250}$ One such institution is the criminal law, which may ban "deviant" sexual conduct outright, or prohibit certain practices that sexual minorities may be siphoned into (like public sex). Same-sex and polyamorous relationships also face stigmatization due to their exclusion from sexually defined institutions like marriage and traditional definitions of the family. Accordingly, these communities face similar choices regarding the targets for political action with regards to their relationships. ${ }^{251}$

The striking parallels raised here suggest that a prospective polyamorous marriage campaign will likely invite similar strategic innovations and raise similar challenges to those seen in the historical gay liberationist

${ }^{247}$ See Jessica Bennett, Polyamory: The Next Sexual Revolution, Newsweer, July 28, 2009, http://www.newsweek.com/polyamory-next-sexual-revolution-82053, archived at http://perma.cc/QM3W-4HT3 (" "This group is really rising up from the underground, emboldened by the success of the gay-marriage movement,' says Glenn Stanton, the director of family studies for Focus on the Family, an evangelical Christian group. 'And while there's part of me that says, "Oh, my goodness, I don't think I could see them make grounds," there's another part of me that says, "Well, just watch them.",").

${ }^{248}$ CAIN, supra note 48 , at 257.

249 Transcript of Oral Argument at 46-47, Hollingsworth v. Perry, 133 S. Ct. 2652 (2013) (No. 12-144), archived at http://perma.cc/5YEK-UXTE.

${ }^{250}$ Constructivist theories in sociology hold that persistent inequalities tend to be perpetuated through multiple institutional arenas of society (i.e., law, medicine, science, media, etc.), which comprise practices and belief systems that privilege one social group over another. See generally Elizabeth A. Armstrong \& Mary Bernstein, Culture, Power, and Institutions: A Multi-institutional Politics Approach to Social Movements, 26 Soc. THEORY 74 (2008) (applying a constructivist approach to the study of social movements). Heteronormativity and monogamy are examples of belief systems that are reinforced through multiple institutional arenas. Id. at 89 (describing "heteronormativity" as "embedded within major institutions" and explaining the "[m]ultisited nature of domination").

${ }^{251}$ For example, in seeking legal recognition for their alternative forms of intimacy, both LGB and polyamorous people are tasked with deciding whether to demand legal rights to marriage - the ready-made, state-sponsored model of intimacy linked to a panoply of rights and benefits - or whether to avoid marriage and pursue piecemeal forms of relationship recognition subsumed within marriage. See infra Part III.C. 
marriage campaigns. Our intention in focusing on the commonalities between these communities is not to make the determinist argument that future polyamorous marriage activism will closely follow the course of LGBT activism. Rather, our aim is to make a case for the utility of the comparative analysis presented in this Article-to demonstrate that the communities are sufficiently similar (in their value orientation and in many structural respects) that the LGBT experience will be informative for polyamorists moving forward. However, as with any comparative research, it is important to be mindful of differences among the compared groups that are likely to create divergence in their actions. For example, polyamorists will likely face unique pressures derived from factors like: the specific cultural history of Mormonism in the United States and use of anti-polygamy laws to assimilate that community ${ }^{252}$ the intersecting stigmatization against multiparty marriage derived from Islamophobia and the deep-seated Orientalism in the West; ${ }^{253}$ and the politicization of multiparty marriage that has arisen from the LGBT movement's same-sex marriage campaign. In the subsequent Parts, we delve further into these and other community-specific differences that are likely to become relevant in evaluating strategies for future polyamorous marriage advocacy.

\section{Legal and Extralegal Lessons From the Marriage Equality Struggle}

The LGBT movement has much to offer for polyamorous activists who are contemplating legal mobilization for multiparty marriage or other nonmarital relationship recognition. In this Part, we map out the set of legal and cultural strategies that the LGBT movement has developed through its multiple decades of litigation in this area, assessing which of these tools would be most relevant to poly activists. Our analysis here draws on the LGBT experience not only to propose a set of strategic tools that poly activists might borrow or avoid, but also to understand how the LGBT movement's own strategic choices may have constrained or enabled the possibilities for poly activism.

${ }^{252}$ See Emens, supra note 25, at 282. Martha Ertman argues that legal restrictions on polygamy derive not only from the threat posed by Mormons' separatism (which challenged U.S. political cohesion), but also to Mormons" "social treason" or "adopt[ion of] a supposedly barbaric [nonwhite] marital form." Martha M. Ertman, Race Treason: The Untold Story of America's Ban on Polygamy, 19 Colum. J. Gender \& L. 287, 287 (2010).

${ }^{253}$ A remarkable recent decision by Utah district court Judge Clark Waddoups used Edward Said's Orientalism framework in analyzing the legal prohibition of polygamy, concluding that "the comparison with non-European peoples and their practices is precisely what made the Mormons' practice of polygamy problematic." Brown v. Buhman, 947 F. Supp. 2d 1170, 1184 (D. Utah 2013). See also Edward W. Said, Orientalism Reconsidered, in Literature, Politics AND Theory 210 (Barker et al. eds., 1986). 


\section{A. Legal Arguments}

\section{Legal Arguments to Borrow}

One of the first accepted legal arguments in the LGBT marriage struggle was an Equal Protection Clause argument based on sex. This argument enjoyed great judicial sympathy in one of the first cases to favorably decide an LGBT rights issue-Baehr v. Lewin, the case discussed in the previous Part. ${ }^{254}$ In Baehr, the Supreme Court of Hawaii found that the prohibition of same-sex marriage constituted discrimination on the basis of sex and required strict scrutiny under the Hawaii Constitution's equal protection clause. ${ }^{255}$ On remand, the circuit court rejected the State's arguments that granting same-sex marriage would harm children, undermine the ability of Hawaii marriages to be recognized in other jurisdictions, and create sizable financial implications for the State, and found the State's prohibitions on same-sex marriage unconstitutional. ${ }^{256}$

The reason for this stringent constitutional test was that the court relied not on the petitioners' sexual orientation, but on their sex, for the equal protection analysis. In other words, "because the state treated female-female and male-male couples differently than female-male couples, it was discriminating because of the sex of one of the partners." ${ }^{257}$ The doctrinal appeal of this argument is obvious: since sex is a suspect classification, relying on sex as the discriminatory category situates discriminatory marriage laws in the context of heightened scrutiny, requiring the state to present compelling reasons to deny the right. 258

The downside of the sex discrimination argument is its reductionist nature. Although it may be empirically difficult to disentangle animus based on sex from animus based on sexual behavior, ${ }^{259}$ outspoken political opposition to LGBT rights and multiparty relationships in the United States strongly suggests that status-based animus against these groups-rather than sexism-is what underlies the dominant monogamous, heterosexual marriage

${ }^{254}$ Baehr v. Lewin, 852 P.2d 44 (Haw. 1993), superseded by constitutional amendment, Haw. Const. art. I, § 23.

${ }^{255} \mathrm{Id}$. at 69.

${ }^{256}$ Baehr v. Miike, No. 91-1394, 1996 WL 694235, at*18-23 (Haw. Cir. Ct. Dec. 3, 1996). Before this decision was reviewed on appeal, Hawaii citizens voted for a constitutional amendment that allowed the Hawaii Legislature the right to ban same-sex marriages, Haw. Const. art. I, $\S 23$, as adopted at Gen. Elec. (Nov. 3, 1998) pursuant to Haw. H.R. Bill No. 117 (1997 Reg. Sess.), which the Legislature subsequently did. Haw. Rev. Stat. § 572-1, as amended by Haw. Sess. Laws 1994, Act 217, § 3.

${ }^{257}$ Eskridge, EQuality Practice, supra note 59, at 8.

${ }^{258}$ Cf. Baehr, 852 P.2d at 580.

${ }^{259}$ See Zachary A. Kramer, Some Preliminary Thoughts on Title VII's Intersexions, 7 Geo. J. Gender \& L. 31, 57 (2006) ("While a plaintiff may identify in a variety of ways and along a series of axes, courts often have trouble parsing between the respective elements of a plaintiff's identity."). 
laws. ${ }^{260}$ Furthermore, it ignores the strong feeling among many queer activists-LGBT, poly, and others-that treating gender as a binary is inherently problematic. ${ }^{261}$

Moreover, in the context of polyamory, the argument will not be incredibly helpful in an era in which same-sex marriage is universally recognized. ${ }^{262}$ A petitioner who wishes to marry a person of the opposite sex and a person of the same sex could face the following mandate: either of the marriages is allowed-so as to avoid discriminating against the petitioner on the basis of sex-but s/he will have to pick which of the two marriages to pursue.

A more promising legal avenue, therefore, would be an Equal Protection Clause argument based on sexual orientation. While sexual orientation, as opposed to race or gender, has not historically been considered a suspect classification that should trigger a strict scrutiny standard, ${ }^{263}$ some recent opinions have awarded it a heightened status. One example is Justice Carlos Moreno's notable dissent to the decision to uphold Proposition 8 in California. ${ }^{264}$ The dissent made it clear that " $[t]$ he question before us is not whether the language inserted into the California Constitution by Proposition 8 discriminates against same-sex couples and denies them equal protection of the law; we already decided in the Marriage Cases that it does." ${ }^{265}$ Rather, the

${ }^{260}$ Cf. Edward Stein, Evaluating the Sex Discrimination Argument for Lesbian and Gay Rights, 49 UCLA L. REv. 471, 503-05 (2001) (arguing that legal claims that homophobic laws constitute sex discrimination avoid the "actual wrong of discrimination on the basis of sexual orientation").

${ }^{261}$ Diane S. Meier, Gender Trouble in the Law: Arguments Against the Use of Status/ Conduct Binaries in Sexual Orientation Law, 15 Wash. \& LeE J. Civil RTs. \& Soc. Just. 147, 163-87 (2008).

${ }^{262}$ Cf. Eskridge, Equality Practice, supra note 59, at 8 (arguing that the "sex discrimination analogy provides no basis for arguing that state refusals to give benefits to cohabiting or polyamorous couples are an invidious kind of discrimination 'like' race discrimination").

${ }^{263}$ In determining whether a group warrants heightened protection under the Equal Protection Clause, the Supreme Court considers history of discrimination, political powerlessness, immutability of the characteristic, and relation of the characteristic to ability to perform or contribute to society. See Frontiero v. Richardson, 411 U.S. 677, 684-86 (1973); see also Marcy Strauss, Reevaluating Suspect Classifications, 35 SEATTLE U. L. REv. 135, 146 (2011) (summarizing the factors for determining suspect classes as: "(1) prejudice against a discrete and insular minority; (2) history of discrimination against the group; (3) the ability of the group to seek political redress (i.e., political powerlessness); (4) the immutability of the group's defining trait; and (5) the relevancy of that trait"). Today, the largest hurdle to obtaining heightened scrutiny for sexual orientation would likely be the "political powerlessness" factor, due to political wins, such as in same-sex marriage, highly ironic considering that the fact that LGB people have suffered a history of discrimination is "not much in debate." Windsor v. United States, 699 F.3d 169, 182 (2d Cir. 2012). Meanwhile, the applicability of the immutability factor for LGB people has been called into substantial question. See Janet E. Halley, The Politics of the Closet: Towards Equal Protection for Gay, Lesbian, and Bisexual Identity, 36 UCLA L. REv. 915, 926-27 (1989) (arguing that courts have retreated from immutability).

${ }^{264}$ Strauss v. Horton, 207 P.3d 48, 128 (Cal. 2009) (Moreno, J., concurring and dissenting).

${ }^{265}$ Id. at 129. 
question was whether such discrimination could be accomplished through a constitutional amendment. ${ }^{266}$ Justice Moreno repeatedly refers to the people who wished to get married as a "suspect classification," arguing that discrimination against them "strikes at the core of the promise of equality that underlies our California Constitution." ${ }^{267}$ For Justice Moreno, all disfavored minorities suffer from a similar rule; it is to defend them that the equal protection clause- "inherently countermajoritarian" by nature-exists. ${ }^{268}$ Justice Moreno's dissent makes it clear that the discrimination category was sexual orientation:

Prior to the enactment of Proposition 8, the California Constitution guaranteed "this basic civil right to all Californians, whether gay or heterosexual, and to same-sex couples as well as to opposite-sex couples. . . . In light of the fundamental nature of the substantive rights embodied in the right to marry-and their central importance to an individual's opportunity to live a happy, meaningful, and satisfying life as a full member of society-the California Constitution properly must be interpreted to guarantee this basic civil right to all individuals and couples, without regard to their sexual orientation." 269

A somewhat different legal tack was adopted by Judge Vaughn Walker of the District Court of the Northern District of California, who based his decision that Proposition 8 violated the Constitution on sexual orientation as well. ${ }^{270}$ For Judge Walker, however, finding that sexual orientation triggers strict scrutiny was unnecessary for the ultimate finding of unconstitutionality. According to Judge Walker, given the illegitimacy of the state interest to ban same-sex marriage, even if sexual orientation were not to be considered a suspect classification, the state would fail the rational basis test. ${ }^{271}$

There are several ways for polyamorous activists to benefit from the sexual-orientation-based equal protection tack, but those would require fashioning a plausible argument according to which, to use Justice Moreno's terminology, polyamorous people are a "disfavored minority" whose discrimination "strikes at the core of the promise of equality" offered to all citizens $^{272}$ - that is, that polyamory should be a suspect classification for the purposes of equal protection. Traditionally, determinations as to whether a social group constitutes a suspect classification have included political powerlessness, a history of discrimination, and an immutable or distinguishing characteristic that bears no relationship to their ability to contribute to

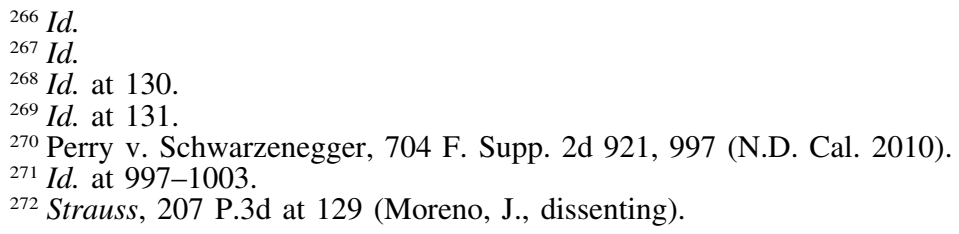


society. ${ }^{273}$ Like the LGBT activists before them, poly activists will likely have no trouble making a case for political powerlessness and history of discrimination; they need only highlight the longstanding political opposition to multiparty marriage in the United States. Furthermore, poly activists may also benefit from the LGBT movement's litigation of the "immutability" prong. In the face of queer and scholarly critiques of immutability arguments for sexual orientation, ${ }^{274}$ LGBT advocates in the mid-1990s collectively decided to avoid such arguments-even as a means of prevailing in court. ${ }^{275}$ Instead, LGBT litigators claimed that a showing of immutability was not actually legally required, ${ }^{276}$ or they would reframe the legal definition of immutability (e.g., as a characteristic that is "so integral to their identity that it would be inappropriate to require them to change it to avoid discrimination"). ${ }^{277}$ Courts have increasingly come to agree with LGBT litigators on these points. ${ }^{278}$ The argument's increasing traction should support "suspect classification" arguments for the poly community; a logical parallel claim in the poly context is that one's orientation toward multiparty relationships is so integral to one's identity that one should not have to change it to avoid discrimination.

An alternative possible path for poly marriage litigation to prevail under an equal protection argument would be for bisexual polyamorous people to make an equal protection claim based on their bisexuality. ${ }^{279} \mathrm{~A}$ bisexual person seeking to marry a member of their own sex and a member of the opposite sex would be the ideal petitioner. However, this approach is not ideal for several reasons. First, the argument would be limited to a fairly narrow subset of the polyamorous community, and presumably not available to heterosexual petitioners wishing to marry several people of the opposite sex or to gay and lesbian petitioners wishing to marry several people of the same sex. Second, the argument would face serious logical challenges. Pre-

${ }^{273}$ See supra note 263; Kenji Yoshino, Assimilationist Bias in Equal Protection: The Visibility Presumption and the Case of “Don't Ask, Don't Tell," 108 YAle L.J. 485, 489 (1998) (discussing the factors the Supreme Court has deployed to determine whether a group is worthy of heightened scrutiny).

${ }_{274}$ See generally Janet E. Halley, Sexual Orientation and the Politics of Biology: A Critique of the Argument from Immutability, 46 Stan. L. Rev. 503 (1994) (arguing that pro-gay legal arguments should focus not on immutability but on common ground that adequately represents the self-conceptions of both essentialists and pro-gay constructivists).

${ }^{275}$ William B. Rubenstein, Divided We Litigate: Addressing Disputes Among Group Members and Lawyers in Civil Rights Campaigns, 106 YALE L.J. 1623, 1643, 1661 (1997).

${ }^{276} I d$. at 1643 .

277 Peter Nicolas, [G]a[y]ffirmative Action: The Constitutionality of Sexual Orientation-Based Affirmative Action Policies, 92 WASH. U. L. REv. 1, 50 (forthcoming 2015).

${ }^{278} I d$.

${ }^{279}$ Michael Boucai makes a related claim that because same-sex marriage bans channel bisexuals into heterosexual relationships, bisexuals may be the ideal carriers of a Lawrence-based sexual liberty argument for same-sex marriage. Michael Boucai, Sexual Liberty and Same-Sex Marriage: An Argument from Bisexuality, 49 SAn Diego L. Rev. 415, 483-86 (2012). 
sumably, the petitioner would try and argue that, but for his/her bisexual orientation, he/she could marry the two (or more) people he/she loves; but straight and gay people do not get to marry more than one person. A possible judicial answer to this argument could be that the petitioner can be married to men and to women, but not simultaneously, and that the possibility of divorce or death followed by remarriage sufficiently allows the petitioner to express his/her bisexual identity. Again, the LGBT movement's expansion of immutability might be used here to expand the pursuit of rights on the part of people whose identity is not as rigidly constructed as genetically or biologically determined identities.

A more inclusive path could be to argue that polyamory itself is a sexual orientation. The benefits here would be that, should the argument succeed, it could advance the goals of a more diverse population, and that it addresses, head-on, the issue of marital exclusivity. Even following the retreat in LGBT advocacy from "hard-wired" immutability arguments, it is likely that advocates for the polyamorous community would have to focus considerable energy to marshal evidence that polyamory is "so fundamental to one's identity that a person should not be required to abandon" it to avoid discrimination. ${ }^{280}$ To the extent that this definition calls for a showing that polyamory is "natural," there have been some efforts in this direction; Christopher Ryan and Cacilda Jethá's recent book, Sex at Dawn, uses evolutionary psychology findings to show that humans most resemble communities of bonobos, for whom sex is a means of social engagement and closeness, and for whom sexual exchanges and promiscuity are an inexorable part of social life. ${ }^{281}$ Based on this and other sources, Ann Tweedy argues that polyamory could be considered a sexual orientation. ${ }^{282}$ Indeed, for some poly activists, being polyamorous is a fundamental part of their self-definition, regardless of their relationship structure at any given time, to the extent that they report that efforts to be monogamous feel unnatural to them. ${ }^{283}$ Notably, one of the difficulties with presenting polyamory as integral to a given person's identity is that evolutionary psychology does not suggest a "Kinsey scale" of propensity toward nonmonogamy; rather, it claims that all humans are, to some degree or other, nonmonogamous. ${ }^{284}$

A potential practical difficulty of the suspect classification argument may be that the Supreme Court has not formally granted heightened scrutiny to any additional groups since the 1970s, when it granted heightened review

${ }^{280}$ Hernandez-Montiel v. INS, 225 F.3d 1084, 1093 (9th Cir. 2000).

${ }^{281}$ Christopher Ryan \& Cacilda Jethá, Sex at Dawn: How We Mate, Why We Stray, and What It Means for Modern Relationships 101-04 (2011).

${ }^{282}$ Ann E. Tweedy, Polyamory as a Sexual Orientation, 79 U. CIN. L. Rev. 1461, 1473-1509 (2011).

${ }^{283}$ Fieldwork, Dec. 2004-Apr. 2005 (on file with first author).

${ }^{284}$ RyAn \& Jethá, supra note 281 , at 98. 
to gender and illegitimacy classifications. ${ }^{285}$ Yet recent developments stemming in part from LGBT movement litigation again limit the challenge here. The Court's recent LGBT rights jurisprudence has suggested that the Court may be moving away from hinging review on a formal finding that a classification falls within one of its traditional three tiers of scrutiny. ${ }^{286}$ These recent cases, while failing to specifically state a standard of review, have invalidated anti-LGBT discrimination using a more robust form of constitutional review than traditional rational basis. ${ }^{287}$ The Court's language suggests that its motivation for using such a heightened form of review was that the regulation in question was so unrelated to its stated goals that it "seems inexplicable by anything but animus toward the class it affects." 288 The long history of discrimination against multiparty relationships, combined with a dearth of evidence that multiparty relationships negatively impact the children of the parties involved, gives pause to arguments that prohibitions against the legal union of those relationships is based on rationality rather than animus. Thus, poly activists may be able to get more searching constitutional scrutiny for discrimination without having to engage with traditional suspect classification analysis.

But even if polyamory does not come to be regarded as a core aspect of personhood that is worthy of special constitutional protection, it may be possible to address the issue by arguing that the state effort to stop multiple marriages does not even amount to rational basis, as in Judge Walker's decision. ${ }^{289}$ For this line of argument to succeed, the state must not even have a legitimate interest in forbidding marriage between more than two people. The arguments presented in Part III.A.2 below would, therefore, need to be defeated.

Another line of argument would pursue the right to marry not as an equal protection issue, but rather on a mandate not to infringe upon a fundamental right. There is, at this point, no question whether there is a fundamental right to marry. ${ }^{290}$ In the context of same-sex marriages, the question raised by opponents was whether "gay marriage" constituted something en-

${ }^{285}$ Lawrence Schlam, Equality in Culture and Law: An Introduction to the Origins and Evolution of the Equal Protection Principle, 24 N. ILl. U. L. Rev. 425, 446-49 (2004).

${ }^{286}$ See, e.g., Lawrence v. Texas, 539 U.S. 558 (2003) (decided in the context of a liberty framework); United States v. Windsor, 133 S. Ct. 2675, 2682 (2013) (arguing for a broad interpretation of immutability, which consists of an inquiry into whether the characteristics of a certain class are the basis for its discrimination).

${ }^{287}$ See Kenji Yoshino, The New Equal Protection, 124 Harv. L. Rev. 747, 755-76 (2011).

${ }^{288}$ Romer v. Evans, 517 U.S. 620, 632 (1996).

${ }^{289}$ Perry v. Schwarzenegger, 704 F. Supp. 2d 921, 997-1003 (N.D. Cal. 2010).

${ }^{290}$ Loving v. Virginia, 388 U.S. 1, 12 (1967) ("The freedom to marry has long been recognized as one of the vital personal rights essential to the orderly pursuit of happiness by free men."). 
tirely different from heterosexual marriage. ${ }^{291}$ And indeed, much of the struggle to receive recognition was focused on presenting same-sex marriages as essentially similar-in love, intimacy, sharing of responsibilities, economic partnership, and a joint project of raising children-to oppositesex marriages. ${ }^{292}$

Similarly, poly marriage advocates will have to argue that, in essence, the right to marry more than one person is nothing but a subset of the more general right to marry. Here, previous litigation in the LGBT and feminist movements has expanded the legal construction of marriage in several ways that may be helpful for poly people. Feminist arguments around contraception and abortion have removed procreation as a crucial function of marriage, ${ }^{293}$ helping advance the conception of "companionate" or romantic marriage that same-sex marriage litigation has further institutionalized. ${ }^{294}$ Thus, if poly activists take the fundamental rights approach-arguing that group marriage enhances the parties' lives in the same way as couple marriages do-the characteristics of marriage they will have to contend with will be: the ability to share love and intimacy; the benefits of long-term commitment; the economic and practical stability of the household; the ability to distribute responsibilities and chores among the different partners; and the child-rearing goals for some relationships. ${ }^{295}$ The courts' openness to a due process argument largely depends on what the state will present as its "legitimate interest" for forbidding group marriage, and two such interests are analyzed below: child-rearing objections and logistical hurdles.

\section{Legal Counterarguments to Watch Out For}

The main (at least ostensibly) nonreligious argument brought against same-sex marriages pertained to the impact of such marriages on children.

${ }^{291}$ For a historical perspective on this line of argument, see James Trosino, American Wedding: Same-Sex Marriage and the Miscegenation Analogy, 73 B.U. L. Rev 93 (1993).

${ }^{292}$ Mike Swift, Census Study of Gay Married Couples Finds Similarities to HusbandWife Couples, San Jose Mercury News (June 17, 2009), http://www.mercurynews.com/ breakingnews/ci_12614608?nclick_check=1, archived at http://perma.cc/4PF5-QH3J ("Demographically, same-sex married couples are more similar to opposite-sex married couples than to unmarried same-sex partners.").

${ }^{293}$ See, e.g., Nan Hunter, Marriage, Law, and Gender: A Feminist Inquiry, 1 L. \& Sexuality: Rev. Lesbian \& Gay Issues 9, 17-18 (1991).

${ }^{294}$ WALZER, supra note 63, at 139 (noting that "if the primary goal of marriage today is to provide love, support, and companionship, then there is no real argument for excluding same-sex couples from such an arrangement").

${ }^{295}$ See, e.g., Roberts v. U.S. Jaycees, 468 U.S. 609, 619-20 (1984) (stating that the types of relationships that fall within the scope of the constitutionally protected right of intimate association include those involving family maintenance, cohabitation, and childrearing); In re Marriage Cases, 183 P.3d 384, 432 (Cal. 2008) ("[P]romoting and facilitating a stable environment for the procreation and raising of children is unquestionably one of the vitally important purposes underlying the institution of marriage and the constitutional right to marry ....."). 
This argument came in several flavors: concerns about discouraging procreation and parenthood by approving partnerships that were not physically capable of producing biological offspring, ${ }^{296}$ and concern about the welfare of children raised by same-sex couples. ${ }^{297}$ We expect the former variant to be less of an issue in the context of polyamorous families, many of which involve partners of both sexes, and the recent decisions to strike down legal provisions that forbid same-sex marriages have repeatedly discredited that line of thought. ${ }^{298}$ More thought should be given to the latter variant of the "think of the children!" argument-namely, the concern that it is unsafe or ill-advised to legitimize child-rearing in multiparent households. Indeed, much of the pro-marriage-equality advocacy in the context of same-sex marriages focused on disproving the notion that same-sex couples were not suitable for child-rearing. ${ }^{299}$ Nonetheless, concerns about child-rearing are still raised in the context of same-sex marriage; in 2014, the State of Utah's brief in the same-sex marriage case there cited a discredited study by Mark Regnerus, a sociology professor at University of Texas at Austin, suggesting that children are harmed by gay marriage. ${ }^{300}$ It is, therefore, a reasonable expectation that such objections will be raised against multiparent households.

Very little scientific literature addresses parenting and child welfare in the polyamorous community save for Elisabeth Sheff's pioneering work. ${ }^{301}$ Sheff's work, based on in-depth interviews with adult polyamorous family members and children, has highlighted several important findings that will hopefully be expanded upon in future research. Young children, Sheff observes, are less likely to be preoccupied with their parents' relationships and number of partners; they relate to the adult members of the household through their particular relationship to each adult, such as "willing to be dressed up" or "bringer of ice cream." 302 Children between nine and twelve

${ }^{296}$ Meredith Clark, Arizona Points to Procreation to Defend Gay Marriage Ban, MSNBC, (July 25, 2014), http://www.msnbc.com/msnbc/arizona-gay-marriage-banabout-kids-lawyers-say, archived at http://perma.cc/BA33-UTGZ.

${ }^{297}$ Mark Regnerus, How Different Are the Adult Children of Parents Who Have Same-Sex Relationships? Findings from the New Family Structures Study, 41 Soc. ScI. REs. 752, 752 (2012).

${ }^{298}$ Golinski v. U.S. Office of Pers. Mgmt., 824 F. Supp. 2d 968, 992 (N.D. Cal. 2012), hearing en banc denied, 680 F.3d 1104 (9th Cir. 2012), appeal dismissed, 724 F.3d 1048 (9th Cir. 2013) ("Furthermore, to the extent Congress was interested merely in encouraging responsible procreation and child-rearing by opposite-sex married couples, a desire to encourage opposite-sex couples to procreate and raise their own children well would not provide a legitimate reason for denying federal recognition of same-sex marriages.").

${ }^{299}$ See Zach Wahls Speaks About Family, YouTube (Feb. 3, 2011), https://www.you tube.com/watch? $=y$ MLZO-sObzQ, archived at https://perma.cc/7GWQ-E6M6.

${ }^{300}$ Reply Brief of Appellants Gary R. Herbert \& Sean D. Reyes at 67, 76, Kitchen v. Herbert, 755 F.3d 1193 (2013) (No. 13-4178) (citing Regnerus, supra note 297).

${ }^{301}$ Elisabeth Sheff, The Polyamorists Next Door: Inside Multiple-Partner Relationships and Families 135-163 (2014).

${ }^{302}$ Id. at 137. 
years old and teenagers tended to be more aware of their parents' lifestyle and made several important observations. First, they felt that they received considerably more attention and supervision than children with monogamous parents-which, while some of them resented it, could be regarded as a positive phenomenon. ${ }^{303}$ Second, as Goldfeder and Sheff observe elsewhere, they felt that different partners brought into the household different parenting strengths, often mentioning being able to talk with one of the partners, or being less able to "get away" with behaviors that the other parents could not cope with. ${ }^{304}$ Third, the children mentioned that instability in the household was a source of sadness and stress for them, and that they missed partners that had left the household. ${ }^{305}$ With regard to this last category, Sheff helpfully compares these teens' experience to that of children of divorced parents, or children in composite families in which some relatives move away. ${ }^{306}$ Similar concerns about stability could be raised about those families, which are not explicitly sanctioned or outlawed.

As more research emerges to support and complement Sheff's findings, ${ }^{307}$ the community may be able to effectively counterargue that polyamorous families are not, per se, harmful to children. Even in the absence of such research, we feel that a fruitful counterargument could rely on the comparison Sheff makes between polyamorous households and households produced by serial monogamies, in which people often stay in touch with former partners and their children while forming new families and having children with new partners. ${ }^{308}$ Since the marriages that produce those families are not under scrutiny, a comparison could be made, arguing that there is nothing endemic to polyamory that produces a worse parenting environment. We expect that divorce and separation statistics may play an important part in attempting to prove that polyamorous families are not, by definition, less stable than monogamous ones, and possibly even that separation in polyamorous families does not typically leave children with a single parent.

It is also possible that concerns about more than two parents can be addressed by referring courts to various contexts in which the law is concerned with single parenting, and with the stereotyping of single parenting as unsuitable for children. If the argument against single parenting relies on the difficulty of providing resources, supervision, and attention without relief

${ }^{303} \mathrm{Id}$. at $139-40$.

${ }^{304}$ Marc Goldfeder \& Elisabeth Sheff, Children of Polyamorous Families: A First Empirical Look, 5 J.L. \& Soc. Deviance 150, 208, 227 (2013), archived at https://perma .cc/9B8W-78MZ.

${ }^{305} \mathrm{Id}$. at 220.

${ }^{306}$ SHEFF, supra note 301, at 139, 142, 267.

${ }^{307}$ Some emerging literature examines these questions in the Australian context. See, e.g., Maria Pallotta-Chiarolli, Polyparents Having Children, Raising Children, Schooling Children, 7 Lesbian \& Gay Psychol. Rev. 48, 48 (2006).

${ }^{308}$ See generally SHEFF, supra note 301. Sheff draws upon E. Mavis Hetherington \& Margaret Stanley-Hagan, The Adjustment of Children with Divorced Parents: A Risk and Resiliency Perspective, 40 J. Child Psychol. \& Psychiatry 129, 129-40 (1999). 
from a second parent, it may well be that multiparent households offer more of those resources.

But there is another argument that might be made against multipartner marriages, which is purely logistical. Since many legal and administrative constructs in the United States rely on the structure of marriage as involving two parties, multipartner relationships create difficult regulative challenges. The classic examples of such challenges are in taxation, health care, and immigration. While opponents to same-sex marriage saw their logistical arguments along these lines rejected, ${ }^{309}$ logistical concerns regarding multiparty marriage may not be so easily dismissed. From a logistical standpoint, legalizing same-sex marriage was hardly a radical move; forms, legal structures, and administrative processes that take into account dyadic marriages are already in place, and the only change is gender. In fact, the changes in tax forms are as minor as the changes in marriage forms, ${ }^{310}$ and same-sex partners whose marriages were federally recognized by Windsor received marriage-based immigration status the very next day. ${ }^{311}$ By contrast, poly marriage advocates will have to confront the state's interest in conserving the resources that would be required by the extension of marital rights and the bureaucratic hassle involved in updating policies, processes, and forms in the three contexts. We proceed to take each one in turn.

In the tax context, federal tax forms require single people to file as single and give married people the choice to file jointly or separately. ${ }^{312}$ While the federal government does not have an explicit policy to reward or penalize marriage, according to the U.S. General Accounting Office's most recent estimates in 2004, there are 198 provisions in the Internal Revenue Code in which marital status factored into individual tax obligations, and 1,138 federal laws in which benefits received or taxes paid depend in some way upon marital status. ${ }^{313}$ Therefore, whether a couple is married or not has genuine tax consequences. Allowing multiple-partner marriage at the federal level might mean allowing more than two partners to file jointly as married, which would require an update of the tax brackets, as well as careful consideration of the tax consequences. It is unclear whether the conventional wis-

${ }^{309}$ See, e.g., Goodridge v. Dep't of Pub. Health, 798 N.E.2d 941, 972 (Mass. 2003) ("Nor can the State's wish to conserve resources be accomplished by invidious distinctions between classes of citizens." (internal citations omitted)).

${ }^{310}$ See, e.g., Marriage Equality in New York City: Questions and Answers for SameSex Couples and All Those Who Wish to Marry Here, OfFice of the City Clerk, New YORK CITY, http://www.cityclerk.nyc.gov/html/marriage/same_sex_couples_faq.shtml, archived at http://perma.cc/M2QK-7MB5.

${ }^{311}$ Julia Preston, Gay Married Man in Florida is Approved for Green Card, N.Y. Times, June 30, 2013, at A11, archived at http://perma.cc/S2GT-5WN8.

${ }^{312}$ Heather M. Field, Choosing Tax: Explicit Elections as an Element of Design in the Federal Income Tax System, 47 Harv. J. ON Legis. 21, 64 (2010).

${ }^{313}$ Margot L. Crandall-Hollick, Molly F. Sherlock \& Carol A. Pettit, Cong. Research Serv., R43157, The Potential Federal Tax Implications of United States v. Windsor (Striking Section 3 of the Defense of Marriage Act (DOMA)): Selected Issues 1 (2013), archived at http://perma.cc/3V9J-ND5W. 
dom, according to which filing jointly is more advantageous for partners with different income levels, ${ }^{314}$ would hold true for partnerships between three, four, or five people. Currently, it is theoretically possible for working polyamorous partners to claim nonworking partners as dependents. ${ }^{315}$ While this possibility will not apply to the entire polyamorous community, it is unclear whether marrying all partners and filing jointly would provide an advantage from the tax perspective. ${ }^{316}$ In any case, it is clear that allowing multiple-partner marriages would require substantial tax reform, the difficulties of which could be claimed as a state interest, and which could be overcome only if courts consider the goal of making marriage available to multiple partners valuable enough to overcome this hassle.

From the perspective of polyamorous marriage activists, a more palatable alternative to asking the government to reform the tax system might be to join the movement to eliminate the marriage election from tax forms. ${ }^{317}$ Proponents argue that, as women enter the workplace, dual-earner families suffer a penalty for joint filing, which is harsher on low-income taxpayers. ${ }^{318}$ Supporting this movement would generate already-existing allies, and may do more for equalizing all kinds of families, not only polyamorous ones.

As an aside, multiple-partner marriages could also be suspected of being pursued with the objective of avoiding the payment of estate taxes, which nonmarried heirs have to pay in the probate process. ${ }^{319}$ But this concern is real only to the extent that the financial advantages involved outweigh the emotional complications, stigma, and other social implications, of being openly married to more than one partner, which means this is probably not a serious concern, or at least not a more serious concern than that of dyadic marriages pursued for strategic ends. ${ }^{320}$

${ }^{314}$ See Adam Bold, When "Married Filing Separately” Makes Sense, Business INSIDER, Feb. 28, 2012, http://www.businessinsider.com/the-rare-cases-when-married-filing -separately-makes-more-sense-2012-2, archived at http://perma.cc/9MFP-AZDZ.

${ }^{315}$ One pertinent scenario is as follows: $\mathrm{A}$ and $\mathrm{B}$ are married and work. C, their third partner, stays home and cares for the family's children. A and B could claim C, as well as the children, as dependents on their tax forms, because the definition of dependent is that of a nonworking person in the household.

${ }^{316}$ See generally William A. Klein, Tax Deductions for Family Care Expenses, 14 B.C. Indus. \& Com. L. Rev. 917 (1973) (arguing that no careful analysis regarding familial status was conducted when creating these deductions, and that much opacity remains).

${ }^{317}$ Harvey S. Rosen, Is It Time to Abandon Joint Filing?, 30 NAT'L TAX J. 423, 423-25 (1977).

${ }^{318}$ Wendy Richards, An Analysis of Recent Tax Reforms from a Marital-Bias Perspective: It Is Time to Oust Marriage from the Tax Code, 2008 WIs. L. REv. 611, 624-26 (2008).

${ }^{319}$ Frank S. Berall, Estate Planning Considerations for Unmarried Same or Opposite Sex Cohabitants, 23 QLR 361, 378 (2004). In fact, estate taxes were the grounds for Edie Windsor's lawsuit: United States $v$. Windsor was won on the premise that requiring Ms. Windsor to pay estate taxes was an impermissible equal protection violation. $133 \mathrm{~S}$. Ct. 2675, 2682 (2013).

${ }^{320}$ For more on this point from a religious polygamous perspective, see Sam Brunson, Polygamous Tax Evasion, By Common Consent (Feb. 24, 2014), http://bycommon 
A second area of law in which marriage sometimes plays a pivotal role is health care. Same-sex marriage advocates focused much energy on concerns about marriage-based health insurance, ${ }^{321}$ as well as on the need to provide partners with a status that would allow hospital visits. ${ }^{322}$ These two issues generate different challenges, with the former addressing the financial rights of partners vis-à-vis employers, and the latter addressing the obligations of hospital personnel to partners and partner decision-making on health issues.

The concern about health insurance raises some issues in the polyamorous context that are unaddressed in the same-sex marriage context. Since health insurance is primarily provided in the United States through employment, ${ }^{323}$ extending benefits to more than one adult person beyond the employee would create a higher burden on the employer. Currently, health benefits are also extended to children, ${ }^{324}$ but assuming that children of poly families receive the benefits through their parents irrespective of the marriage, like children of dyadic families, it will be more of an uphill battle to advocate for insurance benefits extended to more adults. This may mean that spousal insurance, like other benefits extended to partners, may need to become a financial benefit in which the employee has to specify to whom they would like the benefit extended, with a numerical limit on the number of partners.

Concerns about hospital visits from a patient's same-sex partner have raised humanitarian issues of compassion, ${ }^{325}$ and those may arise in the context of polyamorous partners as well; it seems like this may be sorted out through legislation specifically requiring hospitals to allow any partners of the patient to visit. A contractual solution may be advisable in the context of

consent.com/2014/02/24/polygamous-tax-evasion, archived at http://perma.cc/CTF9-RD WR.

${ }^{321}$ Michelle Andrews, Some Same-Sex Couples Denied Family Policies on Insurance Marketplaces, AdvocATE.COM (Feb. 11, 2014), http://www.advocate.com/health/2014/ 02/11/some-same-sex-couples-denied-marketplace\%E2\%80\%99s-family-policies, archived at http://perma.cc/BM5R-HPB2.

${ }^{222}$ See Sunnivie Brydum, WATCH: Gay Man Arrested in Mo. for Refusing to Leave Partner's Hospital Bedside, AdvocAte.com (Apr. 11, 2013), http://www.advocate.com/ politics/marriage-equality/2013/04/11/watch-gay-man-arrested-mo-refusing-leave-part ners-hospital, archived at http://perma.cc/2E6Q-JLKU.

${ }^{323}$ See Margaux J. Hall, Who's the Boss?: Why Are Our Employers Making Our Health Insurance Choices in the First Place?, SLATE (Mar. 24, 2014), http://www.slate .com/articles/news_and_politics/jurisprudence/2014/03/when_did_we_decide_it_was_ok _to_let_our_bosses_choose_our_health_insurance.html, archived at http://perma.cc/23 $\overline{\mathrm{F} F}-\mathrm{QB} \overline{\mathrm{K}} \mathrm{L}$.

${ }^{324}$ See Covering Young Adults Through Their Parents' or Guardians' Health Policy, National Conference of State Legislatures, http://www.ncsl.org/research/health/ dependent-health-coverage-state-implementation.aspx, archived at http://perma.cc/JV2P7PDS

${ }^{325}$ See Nancy Polikoff, HHS Proposed Regs on Hospital Visitation Ignore the Needs of Those Incapable of Naming Visitors, Beyond (Straight and Gay) Marriage (June 25 , 2010), http://beyondstraightandgaymarriage.blogspot.com/2010/06/hhs-proposedregs-on-hospital.html, archived at http://perma.cc/FM64-443K. 
decision-making power for patients unable to express their will. ${ }^{326}$ Controversies abound in struggles between spouses and parents of adult patients, such as the infamous struggle concerning Terry Schiavo. ${ }^{327}$ With the adoption of New York's Family Health Care Decisions Act in 2010, ${ }^{328}$ Missouri is now the only state that does not regulate individuals' rights to make healthcare decisions on behalf of their partners. ${ }^{329}$ State regimes are complemented by federal law, ${ }^{330}$ which expands the decision-making power of partners. Issues of spousal precedence in healthcare decision-making loomed large in debates about gay rights and same-sex marriage. ${ }^{331}$ The universal solution to the problem is to sign an advance healthcare directive, in which a person assigns the power to make healthcare decisions to whomever he or she wishes, be it a legal spouse, a partner, a relative, or a friend. ${ }^{332}$

A bitter struggle might take place in the immigration arena. The United States grants immigrant visas ("green cards") and, consequently, citizenship to spouses of American citizens. ${ }^{333}$ While providing immigration status to same-sex partners of American citizens occurred almost immediately after the decision in United States $v$. Windsor, ${ }^{334}$ immigration authorities may be concerned about sham multiple marriages created solely for the purpose of immigration. Currently, immigration officials conduct interviews with spouses to ensure the genuineness of the marriage, ${ }^{335}$ and there is no reason why such interviews cannot be conducted with more than two partners; given the relatively small percentage of the population involved in multiparty relationships, the costs and logistical hassle will probably be negligible. As it is, a finding that a prospective U.S. entrant professes belief in nonmonogamy in his or her country does not preclude receiving immigration

${ }^{326}$ The recommendation frequently made to families is to create power-of-attorney documents. See Kendell, supra note 224, at 87-88.

${ }^{327}$ Schiavo ex rel. Schindler v. Schiavo, 403 F.3d 1289 (11th Cir. 2005).

${ }^{328}$ NY Public Health $\S \S 63.3$-a et seq.

${ }^{329}$ Jacob Appel, Finally Give N.Y. Families End-of-Life Decisionmaking Power, N.Y. DaILy News (Sept. 6, 2009), http://www.nydailynews.com/opinion/finally-give-n-y-families-end-of-life-decisionmaking-power-article-1.402420, archived at http://perma.cc/ 895J-B66E.

${ }^{330}$ Health Insurance Portability and Accountability Act of 1996 (HIPAA), Pub. L. No. 104-191, 110 Stat. 1936 (1996) (codified in scattered sections of 26, 29, and 42 U.S.C.).

${ }^{331}$ See generally Rebecca K. Glatzer, Equality at the End: Amending State Surrogacy Statutes to Honor Same-Sex Couples' End-of-Life Decisions, 13 ELDER L.J. 255 (2005) (arguing that state surrogate laws should be amended to include nontraditional family members as decision-makers).

332 This is a recommendation frequently extended to any person, regardless of marital status. See Advance Care Directives, American Medical Association, http://www .ama-assn.org/ama/pub/physician-resources/medical-ethics/about-ethics-group/ethics-re source-center/end-of-life-care/advance-care-directives.page?, archived at http://perma.cc/ 8VSR-EHLG.

3338 U.S.C. $§ 1153$ (2012).

${ }^{334}$ See Preston, supra note 311.

${ }^{335}$ David Seminara, Hello, I Love You, Won't You Tell Me Your Name: Inside the Green Card Marriage Phenomenon, Center for Immigration Studies (Nov. 2008), $\mathrm{http} / / / \mathrm{cis}$.org/marriagefraud, archived at http://perma.cc/4BN7-32XK. 
status, ${ }^{336}$ but practicing polygamy, and intending to practice it in the United States, would preclude him or her from receiving an immigrant visa. ${ }^{337}$

Interestingly, immigration law must not have anticipated modern, nonreligious polyamory, as it specifically refers to bigamy based on "historical custom or religious practice." 338 But any argument attempting to distinguish between customary or religious polygamy and nonreligious polyamory might leave the arbitration power as to which multiparty marriage is "legitimate" in the hands of immigration officials, which would be highly problematic. Not only could this create undue discrimination, but absent a change in our approach toward nonmonogamy in general, any nonmonogamous person admitted to the United States on the basis of such a distinction would have to deny-as traditional polygamists do when undergoing immigration proceedings - that he or she intends to practice nonmonogamy after immigration, which would defeat the purpose of granting him or her spousalbased immigration status. It is clear, therefore, that if and when multipartner marriage is recognized nationally, immigration law will have to be carefully and thoughtfully revised.

In summary, polyamorous marriage legal advocates may rely on similar legal arguments to those that same-sex marriage advocates successfully used in court, though they will likely face many new challenges regarding the logistics of legalizing multipartner marriages. We now turn to non-legal dimensions of the marriage equality struggle and their impact on the polyamorous community.

\section{B. Extralegal Strategies and Challenges}

In her article Evaluating Legality, Idit Kostiner argues that activists for legal change view the role of law through three main schemas: instrumental (pursuit of actual, material rights), ${ }^{339}$ political (galvanization of political power for the movement), ${ }^{340}$ and cultural (reception of symbolic recognition and value). ${ }^{341}$ At the end of the article, Kostiner hypothesizes that, as movements grow and mature, they progress from mere instrumental goals to political and cultural goals. ${ }^{342}$

${ }^{336}$ U.S. Dep’t of State, Foreign Affairs Manual Volume 9- 9 FAM 40.101 Notes, http://www.state.gov/documents/organization/87124.pdf, archived at http://perma.cc/RE 4D-H4F8.

${ }^{337} I d$. (An alien may be ineligible for an immigrant visa "if the alien purposely married more than one wife or husband at the same time based on historical custom or religious practice").

${ }^{338} \mathrm{Id}$.

${ }^{339}$ Idit Kostiner, Evaluating Legality: Toward a Cultural Approach to the Study of Law and Social Change, 37 L. \& Soc'y Rev. 323, 335 (2003).

${ }^{340} \mathrm{Id}$. at 339.

${ }^{341} \mathrm{Id}$. at 342 .

${ }^{342} \mathrm{Id}$. at 364. 
As same-sex marriage gained mainstream support subsequent to the completion of the first author's 2005 study on the poly activist community in the San Francisco Bay Area, the polyamorous community may have developed more of a taste for the political and cultural benefits of legal activism..$^{343}$ We now turn to those, and to the extralegal hurdles of cultural backlash.

\section{Strategies to Adopt}

The LGBT movement has experienced a number of extralegal benefits as a result of its advocacy around marriage, which poly activists could effectively adopt. As the history of same-sex marriage activism demonstrates, the movement's focus on marriage helped galvanize the community around the clearly salient issue of relationship recognition, even if its prioritization over other issues was debatable. As Part I shows, pursuing marriage licenses in the early days of gay liberation was a radical, politically transformative act, and it was only later in the history of the movement that it became the vehicle of instrumental rights. Similarly, marriage could potentially play a galvanizing role for poly activists, to the extent that their reluctance to pursue it for political and cultural reasons is less strong. As to the political rationales, polyamorous marriage advocates may find that, in the post-Windsor, postPerry era, focusing on marriage would no longer constitute a risk of sabotage of LGBT struggles, especially given the now commonplace public support for same-sex marriage.

But beyond these tactical considerations, in considering whether to make marriage the focal point of mobilization, the movement will have to overcome its traditional support of free-form, fluid self-determination, free of structural mandates. In 2005, polyamorous interviewees highlighted how important it was for them not to be told "how to do polyamory right," and some of them expressed negative feelings toward certain workshop organizers whose presentation of agreements, jealousy management, and other polyamory relationship practices were, in the interviewees' opinion, patronizing. ${ }^{344}$ Several interviewees also highlighted their strong affinity with the BDSM community, which consistently receives questionable and controversial press coverage, stressing that going "vanilla" for the purpose of achieving legal recognition would be too high a price to pay. ${ }^{345}$ In a similar vein, one important cultural lesson poly activists might take from the LGBT movement's experience dovetails with the concerns raised by polyamorous interviewees in 2005: the choice whether to portray polyamorous partnerships as unique and different from mainstream culture or as similar to monogamous partnerships.

${ }^{343}$ See supra Part II.C.

${ }^{344}$ Aviram, Make Love, Not Law, supra note 26, at 281.

345 Id. at $271-74$. 
In response to these concerns, it is important to keep in mind that the same-sex marriage issue, despite its unifying power, always generated critique from queer and feminist scholars arguing against heteronormativity and assimiliationism, ${ }^{346}$ and that pursuing legal recognition of relationships for those who want them has not precluded the LGBT community from other strands of activism over the years. It is therefore recommended that, like the LGBT community, the polyamorous community adopt a "suits and streets" approach, simultaneously pursuing legal rights in the courtroom and with the legislature and focusing on more radical expressions and goals in public venues, protests, and the media. It may also well be that, before major achievements can occur in the legal arena, poly activists will have to come to the conclusion that the immense symbolic power of marriage in the United States, and the political legitimacy it garners, is well worth the price of assimilation.

In Same Sex Marriage: The Cultural Politics of Love and Law, Kathleen Hull showed how, before the legalization and recognition of same-sex marriage across many states, same-sex couples recurred to symbolic affirmations of their relationships via public commitment rituals, demonstrating how much the appeal to the aesthetics and cultural understandings of marriage meant to the couples that engaged in them. ${ }^{347}$ Similarly, Kimberly Richman's more recent License to Wed included a wealth of interviews with same-sex couples who spoke of the acceptance of their relationships as legitimate and real by family and friends because of the official "stamp" of marriage. 348

Similar issues of acceptance by the outside world are prevalent in the polyamorous community. Polyamorous people report, in the context of therapy, that their nonconventional relationships have caused them alienation from family members and friends who are unable to accept their lifestyle, ${ }^{349}$

${ }^{346}$ See e e.g., Elizabeth Brake, Minimizing Marriage: Marriage, Morality, and THE LAW 120 (2012) ("[S]ome theorists of lesbian, gay, and bisexual oppression have rejected same-sex marriage altogether, arguing that the marital ideal is a heterosexual paradigm.").

${ }^{347}$ Kathleen E. Hull, Same Sex Marriage: The Cultural Politics of Love AND LAW 28 (2006).

${ }^{348}$ Kimberly D. Richman, License to Wed: What Legal Marriage Means to Same-Sex Couples 152 (2014).

${ }^{349}$ Geri Weitzman, Joy Davidson \& Robert A. Phillips, Jr., Nat'l Coal. for Sexual Freedom, What Psychology Professionals Should Know About PolyAMORY 12 (2010), http://instituteforsexuality.com/wp-content/uploads/2014/05/Whattherapists-should-know-about-Polyamory-1.pdf, archived at http://perma.cc/H5XG-5G HK (discussing the fear and stress polyamorous individuals may feel due to keeping their polyamorous relationship secret or leading double lives, family disapproval, and challenges of disclosure to children); see also Keely Kolmes \& Ryan G. Witherspoon, Sexual Orientation Microaggressions in Everyday Life: Expanding our Conversations About Sexual Diversity: Part I, IndeP. Practitioner 96, 98 (Summer 2012), http:// www.drkkolmes.com/docs/kolmes.witherspoon.microaggressions.pdf, archived at http:// perma.cc/Q9CE-JYHF (arguing that therapists should validate multiple partners of patients who experience rejection of their family structure by family and friends). 
difficulties in joining social organizations such as churches, ${ }^{350}$ and sometimes even harassment by adult children seeking to break up their parents' relationships with other partners. ${ }^{351}$ The combination of a more positive public opinion and legal recognition may yield the cultural acceptance that these activists yearn for.

Yet in striving toward cultural acceptance, polyamorous activists must be aware of the possible cultural repercussions of this strategy. The recent visibility of multiparty marriage in the mainstream media provides one example of how public exposure to multiparty relationships might reinforce stereotypes, even if the ostensible intention is to normalize those relationships. In the last decade, there has been an explosion of coverage of, and interest in, polyamorous relationships and lifestyles. ${ }^{352}$ The first television show to portray a nonmonogamous family, Big Love, ${ }^{353}$ was a fictional account of the life of a Mormon businessman married to three women; the show veered between showing the family's everyday life as normal and mainstream and highlighting the nonconventional, and sometimes alarming, aspects of life in the household and in their extended family, including family members living in a religious compound. ${ }^{354}$ Additionally, two reality shows have explored nonmonogamy in very different ways: Sister Wives depicts Kody Brown and his four wives, Meri Brown, Janelle Brown, Christine Brown, and Robyn Sullivan, portraying a normal, low-drama life, ${ }^{355}$ while Polyamory: Married \& Dating focuses on nonmainstream, countercultural young people in the Los Angeles area, portraying their lives as a continuum of drama, orgies, and unstable couplings. ${ }^{356}$ If the community chooses a more mainstream path, its representation in the media may also include child-rearing, household chores, mortgages, and jobs, as the media did for same-sex couples in Queer as Folk and The L Word. ${ }^{357}$

${ }^{350}$ See Polyamory \& Christians, Unitarian Universalists for POlyamory AwARENESS (Apr. 2013), http://www.uupa.org/Literature/Christians.pdf, archived at http://perma.cc/A7G3-3Q68 (attempting to address poly families within the Universalist Unitarian church).

${ }^{351}$ One of the first author's interviewees, a member of a quad, told of the children of one of her partners who outed their father in church and alienated his church-member friends from him until he "reformed" and renounced all partners to whom he was not legally married (interview on file with first author).

${ }^{352}$ Emanuella Grinberg, Polyamory: When Three Isn't a Crowd, CNN (Oct. 26, 2013), http://www.cnn.com/2013/10/26/living/relationships-polyamory/, archived at http://perma.cc/UN4K-BBPT.

${ }^{353}$ Big Love (HBO television broadcast Mar. 2006-Mar. 2011).

${ }^{354}$ See Thomas Buck, Jr., From Big Love to the Big House: Justifying Anti-Polygamy Laws in an Age of Expanding Rights, 26 EMORY InT'L L. Rev. 939, 942-43 (2012).

${ }^{355}$ Sister Wives (TLC television broadcast Sept. 2010-present).

${ }^{356}$ Polyamory: Married \& Dating (Showtime television broadcast July 2012present).

${ }^{357}$ See generally Niall Richardson, Clarissa Smith \& Angela Werndly, Studying Sexualities: Theories, Representations, Cultures 74-75 (2013) (analyzing representation of lesbians on television). 


\section{Extralegal Challenges to Watch Out For}

One concern associated with litigation for rights is the fear of political and social backlash. Indeed, one of the most common critiques of the LGBT impact litigation strategy was the "narrow" use of the courts rather than the usage of more democratic appeals. Some commentators, like Michael Klarman, attribute the enactment of the Defense of Marriage Act to the judicial decision in Baehr. ${ }^{358}$ According to Klarman, the decision was perceived as undue judicial activism, producing federal legislation that limited marriage to one man and one woman. ${ }^{359}$ This interpretation follows, to some extent, the logic of Gerald Rosenberg's The Hollow Hope. ${ }^{360}$ Based on several examples, including Brown v. Board of Education ${ }^{361}$ and its aftermath, Rosenberg argues that seeking rights in the courtroom tends to produce social and political backlash and sometimes an adverse legislative or regulative response. ${ }^{362}$

But critics of Rosenberg's approach argue for a more nuanced understanding of the relationship between litigation and rights, according to which legal victories can, over time, actually facilitate public acceptance even if there is an initial backlash. ${ }^{363}$ Moreover, recent commentary on the same-sex marriage struggle argues that the preemptive anti-gay-marriage countermovement actually served as a catalyst for the very processes it sought to prevent and destroy. ${ }^{364}$

The deep cultural stigma against multiparty marriage in the United States suggests that a poly marriage campaign would likely face an organized conservative backlash of at least the same intensity as the backlash to same-sex marriage. Polyamory is deeply threatening to the mainstream in several psychological and historical ways. While political moderates might not be concerned that providing gay and lesbian people with rights will "infect" heterosexual people with a "gay agenda" or a "gay lifestyle," polyamory strikes at the core of an issue that is pertinent to the life of anyone who has experienced, or is contemplating, questions of love, relationships, and long-term commitment. Fidelity and loyalty, especially through the gendered prism of female chastity, have been fundamental concepts in the creation of the relatively new institution of romantic marriage. ${ }^{365}$ Concerns about abandonment, jealousy, infidelity, and betrayal are at the heart of

${ }^{358}$ KLARMAN, supra note 62, at 212.

${ }^{359} \mathrm{Id}$.

${ }^{360}$ RosenBerG, supra note 149 , at 355-419.

${ }^{361}$ Brown v. Bd. of Educ. of Topeka, Kan., 349 U.S. 294 (1955).

${ }^{362}$ Rosenberg, supra note 149, at 355-419.

${ }^{363}$ See, e.g., Thomas Keck, Beyond Backlash: Assessing the Impact of Judicial Decisions on LGBT Rights, 43 L. \& Soc'Y REV. 151, 152 (2009).

${ }^{364}$ See generally Dorf \& Tarrow, supra note 151 (exploring interview data suggesting that the LGBT movement was brought to the fight for marriage equality by the anticipatory countermobilization of social conservatives who opposed same-sex marriage before there was a realistic prospect of recognition by the courts or political actors).

${ }^{365}$ Stephanie Coontz, Marriage, A History: How love Conquered Marriage 15 (2006). 
much of mainstream discourse regarding romantic commitment. Marriage vows include an edict to "forsak[e] all others." ${ }^{366}$ Sexual betrayal, which is a fairly common phenomenon in monogamous marriages, ${ }^{367}$ is constructed in Western culture as a deal breaker and a legitimate reason for ending the relationship, and even when partners are encouraged to attempt reconciliation, the process can be long and reflect deep trauma. ${ }^{368}$ Mainstream culture holds a great deal of attachment to the idea of sexual exclusivity, and subverting this ethos-albeit, ironically, in the opposite way, honestly and ethically - can constitute a great threat to the symbolic power of sexual fidelity. Moreover, nonmonogamy has yielded very strong antagonistic feelings in the United States, specifically in the context of the historical prohibition of Mormon polygamy in Utah, whose constitution states that plural marriages are "forever prohibited." 369

It is, however, notable that a recent Utah bigamy prosecution against the polygamous Brown family, protagonists of the aforementioned reality show Sister Wives, was dropped. ${ }^{370}$ A subsequent civil lawsuit on behalf of the Browns ${ }^{371}$ resulted in a judicial decision that struck down the anti-cohabitation portion of Utah law as unconstitutional, ${ }^{372}$ based in part on a privacy rationale not unlike the one in Lawrence v. Texas. ${ }^{373}$ Though the prohibition on polygamous marriage remained in effect, commentators considered the law "weakened" by the decision. ${ }^{374}$ The decision is a small but symbolically important victory for multiparty relationships.

${ }^{366}$ See Traditional "I Do" Vows, Wedded Your Way Officiant Services, http:// www.weddedyourway.com/traditional-i-do-vows.html, archived at http://perma.cc/5U XG-SN3R (exemplifying traditional wedding vows).

${ }^{367}$ See Judith Treas \& Deirdre Giesen, Sexual Infidelity Among Married and Cohabiting Americans, 62 J. Marriage \& FAM. 48, 48 (2000) (reporting that between 1.5\% and $3.6 \%$ of married people had had sex with a secondary partner in the past year).

${ }^{368}$ See generally Paul R. Amato \& Denise Previti, People's Reasons for Divorcing: Gender, Social Class, the Life Course, and Adjustment, 24 J. FAM. Issues 602, 621 (2003) (finding that infidelity is the leading reported cause for divorce); Mark H. Butler \& Stephen T. Fife, The Process of Couple Healing Following Infidelity: A Qualitative Study, 6 J. Couple \& Relationship Therapy 1, 10 (2006) (arguing that the process of healing a relationship from the trauma of infidelity is nonlinear).

${ }^{369}$ UtAh CONST. art. III.

370 "Sister Wives" Criminal Charges Case Dropped in Utah, ABC 7 News (June 1, 2012), http://www.wjla.com/articles/2012/06/-sister-wives-criminal-charges-casedropped-in-utah-76552.html, archived at http://perma.cc/NT7P-XKKA.

${ }^{371}$ Reality TV Show Polygamist and His Four Wives Challenge Utah's Bigamy Laws With Support from Their Fellow "Sister Wives," Daily MaIl Online (Jan. 18, 2013), http://www.dailymail.co.uk/news/article-2264326/Sister-Wives-lawsuit-Polygamist-

Kody-Brown-4-wives-challenge-Utahs-bigamy-laws.html, archived at http://perma.cc/ R8DT-6PJK.

${ }^{372}$ Brown v. Buhman, 947 F. Supp. 2d 1170, 1218-21 (D. Utah 2013); see also Bill Mears, Judge Strikes Down Part of Utah's Polygamy Law in "Sister Wives" Case, CNN (Dec. 16, 2013), archived at http://perma.cc/2S5X-NB4D.

373539 U.S. 558, 564-65 (2003).

${ }^{374}$ John Schwartz, A Utah Law Prohibiting Polygamy is Weakened, N.Y. TIMES, Dec. 15, 2013, at A24, archived at http://perma.cc/9XV7-DQMH. 
In addition to the negative stigma from mainstream culture, polyamorous activists frequently complain of antagonism and lack of support from the LGBT community - the very community they wanted to support by suppressing their own potential aspirations to legal recognition. ${ }^{375} \mathrm{~A}$ recent poll in the LGBT magazine The Advocate found close to $70 \%$ of respondents opposing multipartner marriage. ${ }^{376}$ Polyamorous activists need to combat these negative opinions by reaching out to LGBT activists and reminding them of the support they received from the poly community during their struggle for marriage equality.

\section{Alternatives to Marriage}

While polyamorous marriage activists can learn much from same-sex marriage advocacy, they might also learn important lessons from periods and phases in the equality struggle in which activists prioritized other issues over marriage, or perceived them as worthy stepping stones on the way to full equality. Here, we consider two such strategies: antidiscrimination struggles, including workplace discrimination and the struggle against bullying, and various forms of nonmarital relationship recognition, including child custody arrangements, adoption, employment benefits, immigration status for nonmarried partners, and regulatory regimes akin to domestic partnerships that provide bundles of rights that mimic some aspects of marriage.

\section{Anti-Discrimination, Anti-Bullying}

Looking outside the sphere of relationship recognition and into areas of public life, such as employment and education, might be a more hopeful strategy for poly activists seeking quicker signs of progress for polyamorous individuals. In the LGBT movement's case, litigation targeting the public realm gained cultural and legal acceptance more quickly than litigation targeting the private realm. ${ }^{377}$ In terms of cultural acceptance, employment discrimination was one of the arenas in which public opinion regarding the LGBT community changed most quickly, with a majority turning in favor of workplace protections for sexual orientation as early as the 1990s. ${ }^{378}$ Meanwhile, public opinion on relationship recognition and same-sex marriage has remained steadily negative, experiencing an uptick only very recently. ${ }^{379}$ In terms of legal victories, Patricia Cain has pointed out that "the greatest

${ }^{375}$ Aviram, Make Love, Not Law, supra note 26, at 273-74.

376 The Advocate Poll, supra note 36, at 10.

${ }^{377}$ CAIN, supra note 48, at 167.

378 Andrew R. Flores, Williams Inst., National Trends in Public Opinion on LGBT Rights in the United States 25 (2014), archived at http://perma.cc/4J8GLR7M.

${ }^{379}$ See Marriage, GalluP, http://www.gallup.com/poll/117328/marriage.aspx, archived at http://perma.cc/BAG6-L3RB. 
gains" in the first few decades of LGBT impact litigation "were in the public sphere," such as in the areas of free speech and public education. ${ }^{380}$ The movement at the time saw far fewer victories in the area of family law; "[n]o court ruled in favor of recognizing the legal right of lesbian and gay partners to share their lives, to be together, to claim that they were a family." 381

Employment discrimination is a particularly advantageous area for pursuing rights and public recognition because it appeals to a dominant sensibility according to which employment should reflect merit rather than discriminatory notions unrelated to the job. However, litigation in this context should be pursued deliberately and carefully, as some areas of employment may be easier to litigate than others; for example, LGBT activists have faced more problems in the context of employment in K-12 education. ${ }^{382}$ It is important to point out that this public sensibility has been fueled by the rhetoric of previous civil rights struggles and judicial interpretation, which define discrimination as irrational individual animus. ${ }^{383}$

In recent years, much of the energy of the LGBT community in the public rather than private sphere has been directed toward anti-bullying campaigns, through initiatives such as the It Gets Better initiative ${ }^{384}$ and the Trevor Project, ${ }^{385}$ which attract many straight allies to empower gay children, teens, and adolescents and protect them from harm. Similar energies can be put into protecting children in multiparent families from harassment and hassle regarding their family structure.

\section{Nonmarital Relationship Recognition}

Other avenues that polyamorous activists may choose to focus on, in lieu of formal marriage or as a precursor to it, are various forms of relationship recognition. One particularly important issue pertains to parental rights. There have been documented cases in which polyamorous people have lost custody of their children because of judicial antipathy toward their family

${ }^{380}$ CAIN, supra note 48, at 167.

${ }^{381} \mathrm{Id}$.

${ }^{382}$ See generally Jeffrey I. Bedell, Personal Liability of School Officials Under $\S 1983$ who Ignore Peer Harassment of Gay Students, 2003 U. ILL. L. Rev. 829, 833-47 (2003) (arguing that current interpretations of Title IX and Title VII cannot redress antigay harassment).

${ }^{383}$ See Samuel R. Bagenstos, The Structural Turn and the Limits of Antidiscrimination Law, 94 CALIF. L. REv. 1, 45 (2006) (stating the intent-based understanding of discrimination is evident in both the decline in disparate impact doctrine and courts' hesitation to read disparate treatment doctrine as embracing implicit or subconscious bias).

${ }^{384}$ It Gets Better Project: Give Hope to LGBT Youth, www.itgetsbetter.org/, archived at http://perma.cc/M9LY-T4FB.

${ }^{385}$ The TREvor Project, www.thetrevorproject.org/, archived at http://perma.cc/ Y5S8-DZNS. 
structure, ${ }^{386}$ but there are already documented early successes in which stable, normative, responsible three-parent families have prevailed in custody battles. ${ }^{387}$ The availability of three-parent adoption as a legal recourse was not intended to accommodate polyamorous parents_-indeed, when hailed by supportive politicians in the media, the examples provided included amicable divorces and same-sex couples in close communication with the biological parent ${ }^{388}$ - but it can be a useful legal vehicle in such cases. Additionally, as mentioned above in our discussion of health care, flexible negotiation of employment benefits might not generate a problem for the employer as long as, for example, the employee chooses which of his or her partners is to receive the benefits.

As explained in Part II above, LGBT impact litigation in the early 1990s prioritized these alternative means of relationship recognition, garnering so much support that same-sex marriage antagonists argued later that the existence of civil unions and domestic partnerships rendered same-sex marriage unnecessary. ${ }^{389}$ It is perhaps difficult, but not impossible, to imagine that such alternative frameworks may be more palatable to the mainstream public, who might understand the need for a "special arrangement" for a few unique nonmonogamous families without changing the framework of the institution of marriage.

\section{The Shadow of Marriage}

In light of these alternative litigation options, why should polyamorous activists be concerned with marriage? It may be that, even if polys decide to pursue nonmarital forms of relationship recognition, the incredible cultural and social resonance marriage has in defining what relationships are worthy of legal protection will make it an impossible subject for poly activists to avoid. As discussed in Part I.C, even when LGBT activists have pursued alternatives to marriage, it has been exceedingly difficult for them not to use marriage as a key reference point and model for arguments regarding the types of relationships that merit recognition. ${ }^{390}$

${ }^{386}$ See PolyFamily Child Custody Case Ends After 2 Year Battle, Polyamory SocIETY, http://www.polyamorysociety.org/Divilbiss_Families_Case_Ends.html, archived at http://perma.cc/UC52-NACA (explaining the April Divilbiss case).

${ }^{387}$ Amy Nash-Kille and her two husbands prevailed in such a case in Portland, Oregon, and have also achieved a three-parent adoption of their children. Amy Nash-Kille, Presentation at the University of California Hastings College of the Law Criminalization and Social Control Seminar (Oct. 6, 2014); Amy Nash-Kille, Presentation at the International Conference on the Future of Monogamy and Nonmonogamy in Berkeley, CA (Feb. $23,2014)$.

${ }^{388}$ Ian Lovett, Measure Opens the Door to Three Parents, or Four, N.Y. Times, July 13, 2012, at A9, archived at http://perma.cc/JFN9-NBAA.

${ }^{389}$ See, e.g., Kerrigan v. Comm'r of Pub. Health, 909 A.2d 89, 94-96 (Conn. Super. Ct. 2006) (same-sex couples could not establish discrimination based on sex because of the state's civil union law granting equal benefits).

${ }^{390}$ See supra Part I.C; see also NeJaime, Before Marriage, supra note 82, at 113. 
Furthermore, even if attorneys in the nonmarital same-sex relationship recognition cases had chosen to highlight alternative sexual affiliations and family structures that were not "marriage-like," it is unclear what meaning the public or the courts would take away from those narratives. ${ }^{391}$ Marriage is so deeply embedded within dominant cultural definitions of intimacy, or as a dominant cultural schema for understanding and evaluating intimate relationships, ${ }^{392}$ that it is difficult to imagine it would not end up playing a role in any public poly relationship recognition campaign. Indeed, media coverage of the LGBT movement's nonmarital recognition cases of the 1990s often framed them as proto-marriage-equality cases, attributing the cases' origins to marriage laws that were out of touch with an emerging social reality. ${ }^{393}$

Poly advocates should consider the danger that their litigation campaigns_-regardless of whether they directly advocate for poly marriage or whether they advocate for nonmarital forms of poly relationship recognitions-are prepared to evoke public scrutiny of poly relationships that holds those relationships to the dominant marriage-like frame for intimate adult relationships. It may be possible for the immense symbolic potential of marriage to work to the advantage of poly advocates, helping them usher in relationship recognition mechanisms under the backdrop of marriage as a powerful frame for garnering legitimacy. Yet polyamorous activists must strongly consider how evoking marriage may just as soon work to assimilate poly communities as to offer a stepping stone to more transformative visions of intimacy, which may lead to socio-legal outcomes that are more to the liking of some polyamorous people than others, and more conducive to support some poly relationship structures than others.

\section{Discussion AND Implications}

Taken together, the analysis in Part III suggests that the LGBT legal mobilization may have produced conflicting pressures for the contemporary poly community. On one hand, we have identified numerous areas in which same-sex marriage litigation has expanded the doctrinal resonance of legal arguments in favor of polyamorous marriage (or other forms of relationship recognition). Yet a theme that also emerges from this analysis is how LGBT legal mobilization for same-sex marriage may have reinforced cultural stigmas against polyamorous relationships. This Part turns to further considering this possibility, and its implications for the scholarly understandings of law and social movements.

${ }^{391}$ See supra Part I.C (discussing the media's framing of relationship recognition cases in marital terms).

${ }^{392}$ See Areila R. Dubler, Wifely Behavior: A Legal History of Acting Married, 100 Colum. L. Rev. 957, 1009 (2000).

${ }^{393}$ See Stroock, supra note 136; Margolick, supra note 137. 
What effect has LGBT movement advocacy for same-sex marriage had on cultural constructions of polyamorous people? At the very least, same-sex marriage litigation appears to have opened the door to a renewed national discussion about multiparty marriage. As noted earlier, the issue of polyamory (or polygamy) is often raised in same-sex marriage cases as part of the inevitable "slippery slope" argument against expanding marriage to LGB couples. The inevitable slippery-slope-to-polygamy arguments that arise in same-sex marriage litigation are often centrally featured in media coverage of those cases, ${ }^{394}$ providing a compelling hook for reader interest. To the extent that this coverage connects multiparty marriage to a frightening possible consequence of same-sex marriage recognition, the media is unlikely to ameliorate polyamory's stigmatized status.

Furthermore, LGBT advocates have countered slippery slope arguments by drawing a bright line between same-sex couples and multiparty relationships, ${ }^{395}$ which may have furthered the stigmatization of polyamorous individuals. This strategy acquiesces to the unspoken message in the conservative arguments: that multiparty relationships are of less value than monogamous ones and undeserving of the sanctity of marriage. Thus, the public discourse LGBT advocates have sparked around polyamory has not been a debate, but rather a one-sided reinforcement of the dominant view that polyamorous relationships are beyond the scope of accepted sexual mores. This public positioning of LGB people as distinct from polyamoristsand closer to the mainstream-may have furthered the stigmatization of polyamorous communities. While (straight, monogamous) mainstream public discourse rejecting polyamory reinforces dominant sexual norms, LGBT community discourse rejecting polyamory adds additional texture to the hierarchy of sexual norms and stigmatization. When LGBT advocates-themselves on the fringes of the mainstream-distance themselves from polyamorists, the latter are pushed even further to the margins. 396

In addition, same-sex marriage litigation may have increased the stigmatization of polyamorous people by opening them up to conservative backlash-or "forelash," given that polyamorists have yet to mobilize en masse. Polyamory has been a constant focus of opposition to same-sex marriage, figuring strongly in arguments made both inside and outside the courtroom.

${ }^{394}$ See, e.g., Kirk Johnson, Iowa Justices Hear Same-Sex Marriage Case, N.Y. Times, Dec. 10, 2008, at A24, archived at http://perma.cc/Z35G-MND7 (opening with the following sentence: "In a case that could make Iowa the first Midwestern state to legalize same-sex marriage, the Iowa Supreme Court on Tuesday pressed lawyers for both sides with sharp questions on topics like the 4,000-year-old history of marriage and whether a ruling favoring gay couples would open the door to polygamy.").

395 Transcript of Oral Argument at 46-47, Hollingsworth v. Perry, 133 S. Ct. 2652 (2013) (No. 12-144), http://www.supremecourt.gov/oral_arguments/argument_tran scripts/12-144a.pdf, archived at http://perma.cc/5YEK-UXTE.

${ }^{396}$ Cf. Katherine M. Franke, The Domesticated Liberty of Lawrence v. Texas, 104 Colum. L. Rev. 1399, 1413-16 (2004) (arguing that the LGBT movement's quest for marriage further stigmatizes those who engage in sexual conduct outside committed, monogamous relationships). 
For example, the year after the Massachusetts Supreme Judicial Court found bans on same-sex marriage unconstitutional, ${ }^{397}$ the Family Research Council issued a pamphlet entitled "The Slippery Slope of Same-Sex Marriage." 398 After describing polyamory as a new front of the "movement to redefine marriage," the pamphlet argues that, like same-sex marriage, polyamory "looms ahead for our society unless a bulwark is created in the form of a constitutional amendment protecting marriage." ${ }^{399}$ In 2008, another of the major organizations leading the fight against same-sex marriage, Focus on the Family, issued a similar statement raising the threat of polyamorist relationship recognition "on the heels" of LGBT movement victories in the marriage realm. ${ }^{400}$ While this earlier attention to polyamory seems to have been an offshoot of conservative efforts to hobble same-sex marriage, more recent rhetoric indicates that conservatives are starting to focus on polyamory as an issue in its own right. ${ }^{401}$ It could be, as one polyamorous blogger suggested, that conservatives are increasingly giving up the ghost on samesex marriage and are instead "turning their sights more directly onto the next target down their slippery slope." 402

In raising the potential cultural consequences of same-sex marriage litigation on a prospective polyamorous marriage campaign, we are not suggesting that LGBT movement activists should be held responsible for these consequences. Many of the consequences we mention, such as the media attention to and conservative backlash against polyamory, have occurred in areas outside the LGBT movement's control. For the areas within activist control, such as litigators' strategic line-drawing and disassociation from polyamorists, it is difficult to pass judgment without full awareness of the competing pressures that motivated LGBT activists' strategic decisions. The

${ }^{397}$ Goodridge v. Dep't of Pub. Health, 798 N.E.2d 941, 948 (Mass. 2003).

398 Timothy J. Dailey, Family Research Council, The Slippery Slope of SameSex Marriage (2004), http://downloads.frc.org/EF/EF04C51.pdf, archived at http://per ma.cc/D9G9-QZEQ.

${ }^{399} I d$.

${ }^{400}$ Focus on the Family Issue Analysts, Marriage, Focus on THE FAMILy (2008), http://www.focusonthefamily.com/socialissues/social-issues/marriage.aspx, archived at http://perma.cc/8WBZ-ERXQ.

${ }^{401}$ See, e.g., Jennifer Leclaire, Forget Gay Marriage, Mainstream Media Now Pushing Polyamory, Charisma News (Feb. 21, 2013), http://www.charismanews.com/opinion/watchman-on-the-wall/42881-forget-gay-marriage-mainstream-media-now-pushingpolyamory, archived at http://perma.cc/PTD6-QZWA; Patrick F. Fagan, Domestic Disturbances: The Rising Polyamorous Culture is Out to Get Your Children, Touchstone: A Journal of Mere Christianity, Jan./Feb. 2010, archived at http://perma.cc/9TWBDKFR (arguing that a culture war has broken out between the "culture of polyamory" and the "culture of monogamy," but making no mention of LGBT people or same-sex marriage); see also Bennett, supra note 247 (stating that polyamorists "are beginning to show up on the radar screen of the religious right, some of whose leaders have publicly condemned polyamory as one of a host of deviant behaviors sure to become normalized if gay marriage wins federal sanction").

${ }^{402}$ See Alan, Conservatives Shifting their Aim to Polyamory, Polyamory IN THE News (Dec. 9, 2013), http://polyinthemedia.blogspot.com/2013/12/conservatives-shift ing-their-aim-to.html, archived at http://perma.cc/S96P-ZKCR. 
major point here, as throughout the Article, is to assess the legal and cultural tools and obstacles that polyamorists are likely to encounter in the road ahead. The discussion here specifies particular environmental changes that have emerged from the LGBT movement's marriage campaign, which may hinder the viability of the favorable legal arguments that the LGBT movement has simultaneously put into effect.

An additional contribution of this discussion is to help build understandings of the far-reaching effects that one social movement's actions may have (even inadvertently) on another social movement. This Article has shown how the mainstream LGBT movement, which had almost no formal engagement with polyamorous activists, has had profound implications for that group and its potential for future mobilization. This idea of movementmovement influence resonates with a large body of socio-legal work on social movement "spillover," or the impact of previous social movements on subsequent ones. ${ }^{403}$ In a foundational article investigating the influence of the women's movement on the U.S. peace movement, sociologists David Meyer and Nancy Whittier identify four major types of social movement spillover: the adoption of a previous movement's political "frames"; the spread of innovative protest tactics; the selection of leadership; and the implementation of common organizational structures. ${ }^{404}$ One of the key mechanisms that allows for these spillover effects to occur, according to Meyer and Whittier, is when one movement achieves certain change in the external environment, which subsequently restructures the opportunities and challenges available to the next movement. ${ }^{405}$ The present Article contributes to these sociological insights by applying these theories in the context of social movement legal mobilization. As a result, we identify different forms of spillover that sociologists have largely ignored, including not only the doctrinal legal arguments presented in court, but perhaps more importantly, the various cultural models of litigation that a movement can use to achieve different extralegal goals (e.g., to the radical "litigation as protest" model versus the more traditional impact litigation model). These socio-legal movement strategies, which do not fit neatly into the categories of spillover identified in Meyer and Whittier's sociological work, suggest a more complex type of spillover may be at play in legal mobilization.

An additional benefit of investigating social movement spillover in the context of legal mobilization is that it allows for a more nuanced understanding of the interrelated movement-inspired changes in both cultural and legal environments, which subsequently shape future movements. Previous research has tended to conceptualize a movement's impact on its external environment as either cultural or legal; cultural impact is usually defined as

${ }^{403}$ Meyer \& Whittier, supra note 24, 277-78.

${ }^{404} \mathrm{Id}$. at 278.

${ }^{405} I d$. at 281 ("The cultural changes promoted by a social movement affect not only the external environment but also other social movements."). 
spreading movement-related ideologies (e.g., feminist or antiracist ideals, which future movements import), ${ }^{406}$ while legal impact may be measured by winning precedent on particular legal arguments. Our approach in this Article incorporates a socio-legal perspective into the idea of environmental change, which sees law and culture as mutually influential and overlapping spheres of social life. For example, in evaluating the potential spillover of LGBT legal strategies, we have weighed not only their resonance with existing doctrine but also their cultural meaning and messaging effect. Similarly, we have discussed how the numerous cultural effects of social movement litigation can seep into and affect other communities' possibilities for legal mobilization. Our identification of these cultural effects of litigation outside of a single litigating movement has opened a fruitful area for further empirical exploration.

\section{CONCLUSION}

This Article has identified a common set of characteristics that the polyamorous community today shares with the gay liberationists of the early 1970s who initially pushed for same-sex marriage_-suggesting a ripe setting for the diffusion of marriage equality strategies from the LGBT movement to the poly context. We have also suggested that the LGBT movement's longstanding legal mobilization around issues of legal relationship recognition, both through marriage and other legal frames, has shaped the contemporary landscape for poly activism in ways that are likely to constrain the cultural resonance of poly marriage, while simultaneously bolstering the legal resonance of constitutional arguments for poly marriage. By examining the potential strategy diffusion between these movements, and how the possibilities for such diffusion are partially contingent on the environmental changes brought about by previous LGBT movement mobilization, this project has forged a path for theoretical development around issues of social movement spillover.

In addition to its theoretical contributions, this Article is useful for its practical utility. Part III provides the first roadmap of issues, strategies, and challenges that advocates can expect to see in the path toward polyamorous marriage or other legal relationship recognition. Incorporated in our discussion of potential poly strategies is a sensitivity to the interaction between the legal and cultural implications of social movement litigation that is rare in legal scholarship-especially in legal scholarship that aims to have a practical impact, as ours does. For instance, even as we outline several legal arguments that have become accepted and endorsed by judges that would be favorable to a poly marriage campaign, we have also identified the potentially culturally problematic aspects of those arguments. Arguments in the 
post-Baehr same-sex marriage context, which continue to exalt marriage as an intimate expression of identity and as a primary vehicle for family formation, may be strategically effective for winning in court, while simultaneously chafing those in the poly community who hope to "queer" marriage or think more broadly about their community.

Along with the typical impact litigation strategies, the history of LGB relationship recognition litigation provides several examples of litigation strategies that may be better suited to the poly community's nonlegal cultural goals. The nonmarital relationship recognition approach may be more effective at reducing stigma against alternative family forms and building ties with allied political movements, such as the movement to remove the marriage election from the tax code and the movement for universal healthcare. The "litigation as protest" approach-advocating for marriage before it is legally viable-may be more effective at pointing out the discriminatory effects of marriage laws and challenging the dominance of marriage as an institution. While these alternative models for legal mobilization from the LGBT context might not have been the surest winners in the courtroom (at least initially), it is important to signal the opportunities they might present for poly activists seeking other types of goals.

Thus, our practical roadmap for poly activists is unique in that it does not assume that winning is, or should be, the purpose of poly marriage litigation. As the experience of the LGBT movement suggests, pursuing an approach that is narrowly targeted at legal reform will not always get at the movement's core motivations for litigating. Our purpose in tracing the multiple models of relationship recognition mobilization in the LGBT context has been to show poly activists how litigation can satisfy a range of movement imperatives, from the formalistic, to the immediate and practical, to the radical.

At this juncture, it is up to poly people to decide what is at the core of their politics. Is it the affirmation and recognition of poly lifestyles that marriage provides (an identity politics movement)? The freedom to define one's family and lifestyle without state interference (a liberal rights issue)? The redistribution of social wealth to bridge the economic gap between statesanctioned couples and others, such as nonsexual co-parents, extended families, care-giving relationships, and elderly companions (a social justice issue)? In presenting the LGBT movement's experience with multiple models for legal mobilization, and showing how those models link with various underlying motivations for legal change, our hope is not to direct the course of poly advocacy, but rather to provide tools and perspectives for them to use in constructing a nuanced and historically informed mobilization strategyif they so desire. 